\title{
Paleogene Stratigraphy of the Putneys Mill, New Kent County, Virginia, Corehole
}

By Laurel M. Bybell and Thomas G. Gibson

This report is preliminary and has not been reviewed for conformity with U. S. Geological Survey editorial standards or with the North American Stratigraphic Code 


\section{CONTENTS}

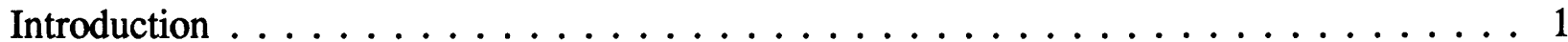

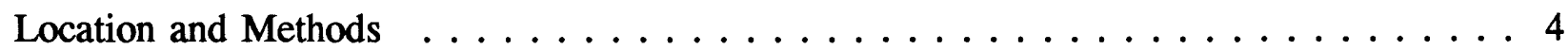

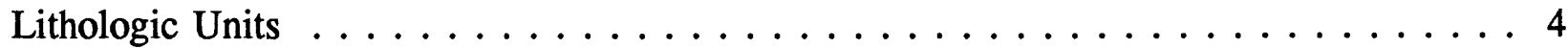

Marlboro Clay . . . . . . . . . . . . . . . . . 4

Nanjemoy Formation . . . . . . . . . . . . . . . 5

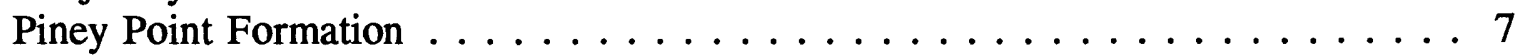

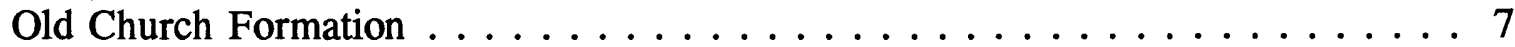

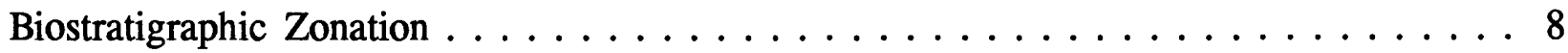

Calcareous Nannofossil Zonal Indicators $\ldots \ldots \ldots \ldots \ldots$

Marlboro Clay . . . . . . . . . . . . . . . . . . . . 10

Nanjemoy Formation . . . . . . . . . . . . . . . . . 11

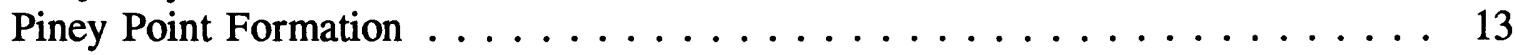

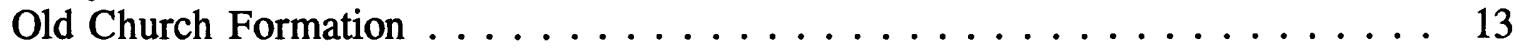

Relationship of Putneys Mill corehole strata $\ldots \ldots \ldots \ldots \ldots \ldots \ldots$

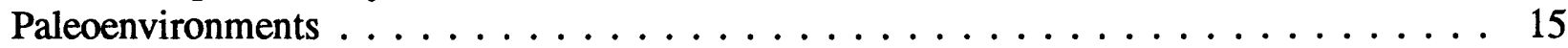

Marlboro Clay . . . . . . . . . . . . . . . . . . 16

Nanjemoy Formation . . . . . . . . . . . . . . . . 18

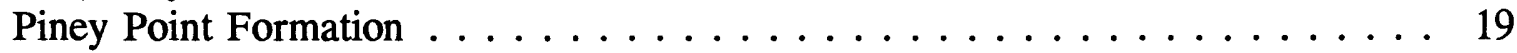

Old Church Formation . . . . . . . . . . . . . . . . 20

Clay Mineralogy of the Marlboro Clay . . . . . . . . . . . . . 20

Putneys Mill Lithic Summary . . . . . . . . . . . . . . . . . . 21

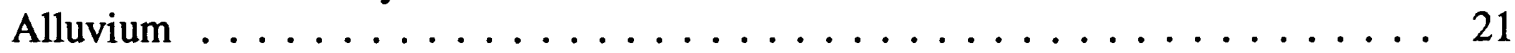

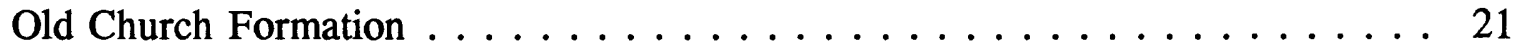

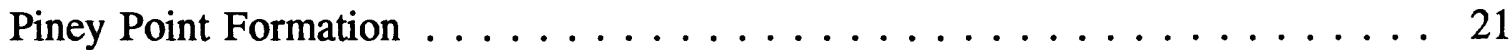

Nanjemoy Formation . . . . . . . . . . . . . . . 22

Marlboro Clay . . . . . . . . . . . . . . . . . . . 23

Acknowledgments ......................... 24

References . . . . . . . . . . . . . . . . . . . . 25

Appendix 1. On-Site Core Description . . . . . . . . . . . . . . . . . . 29

Appendix 2. Calcareous Nannofossil Species Listed in Paper . . . . . . . . . 36

\section{ILLUSTRATIONS}

Figure 1. Location map for Putneys Mill and other coreholes discussed in text.

Figure 2. Stratigraphic summary of Putneys Mill corehole and tau values.

Figure 3. Calcareous nannofossil occurrence chart.

Figure 4. Correlation chart of Eocene and Oligocene strata in Oak Grove, Putneys Mill, and Haynesville coreholes.

Table 1. Percentage composition of clay mineral suite in the Marlboro Clay of the Putneys Mill corehole. 


\title{
PALEOGENE STRATIGRAPHY OF THE PUTNEYS MILL COREHOLE,
}

\author{
NEW KENT COUNTY, VIRGINIA
}

\author{
By LAUREL M. BYBELL and THOMAS G. GIBSON
}

\section{INTRODUCTION}

In the central part of the Salisbury embayment (southern Maryland and northern Virginia), the lower Eocene Nanjemoy Formation is exposed in a series of extensive but discontinuous outcrops in its type area along the Potomac River (fig. 1). Clark and Martin (1901) pieced together these outcrop sections and constructed a relatively continuous section for the Nanjemoy. Drilling of the continuously cored U.S. Geological Survey (USGS) Oak Grove drillhole in northern Virginia in 1976 (fig. 1) provided a nearby subsurface reference section for the entire Nanjemoy Formation, as well as for the underlying upper Paleocene Marlboro and Aquia Formations (Reinhardt and others, 1980; Gibson and others, 1980). A somewhat further downbasin section of these formations was penetrated in the USGS Haynesville corehole (fig. 1) (Mixon and others, 1989).

In the southwestern part of the Salisbury embayment, however, outcrops of the Nanjemoy Formation are limited both in their number and in the amount of section exposed, and little is known of the stratigraphy of the entire formation in this area. In 1979, the Putneys Mill corehole was drilled along the Pamunkey River (fig. 1) to improve our understanding of the stratigraphy of the lower Eocene Nanjemoy Formation in central Virginia. From oldest to youngest (Paleocene to Oligocene), this corehole recovered Paleogene sediments of the Marlboro Clay, Nanjemoy Formation, Piney Point Formation, and Old Church Formation (fig. 2). This corehole provides an important reference section for the Nanjemoy Formation in central Virginia, as well as for the overlying, middle Eocene Piney Point Formation. The Marlboro Clay and Old Church Formation are represented by thin or incomplete sections in the Putneys Mill core.

Studies on the physical stratigraphy and on various fossil groups from the Paleogene strata in the Pamunkey River area are contained in a guidebook for the 1984 Field Trip of the Atlantic Coastal Plain Geological Association. These articles include the stratigraphy of the outcropping Paleogene beds along the Pamunkey River (Ward, 1984), calcareous nannofossils from Piney Point Formation outcrops (DiMarzio, 1984), dinocysts of the Piney Point and Old Church Formations from Pamunkey River outcrops and the Putneys Mill corehole (Edwards, 1984), sporomorphs from Piney Point and Old Church Formation outcrops (Frederiksen, 1984), mollusks from outcrops of the Piney Point and Nanjemoy Formations (Strickland, 1984; Morrell, 1984), ostracodes from Piney Point Formation outcrops (Deck, 1984), barnacles from outcrops of the Old Church Formation (Zullo, 1984), and the biostratigraphy of various vertebrate groups from outcropping Paleogene strata (Weems, 1984). Ward (1985) reported on molluscan studies and surface stratigraphic investigations of the Paleogene strata of Virginia and Maryland, including the Paleogene strata along the Pamunkey River. 


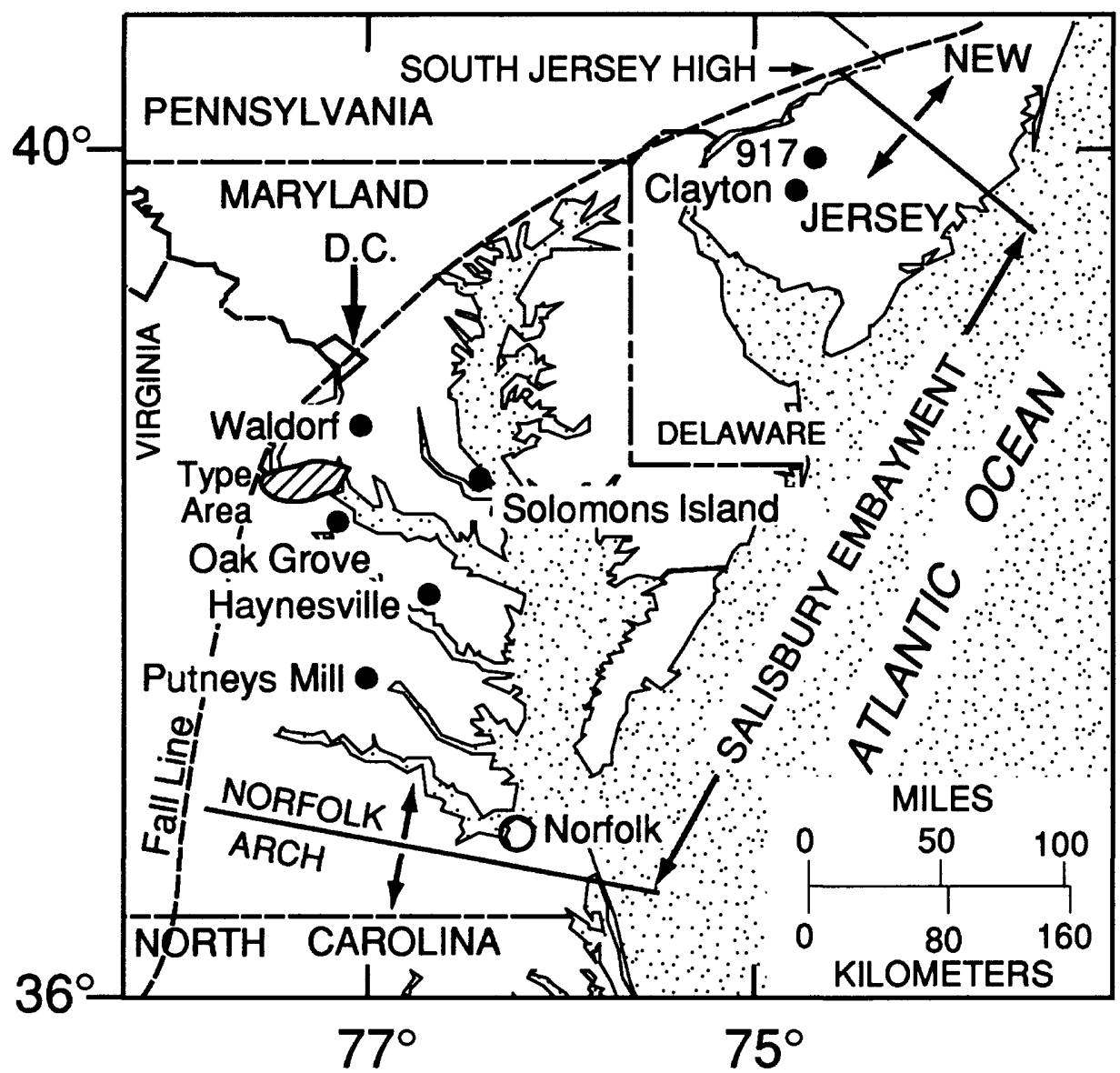

Figure 1. Map of Salisbury embayment showing location of Putneys Mill corehole, other coreholes discussed in text, and type area of Aquia and Nanjemoy formations. 


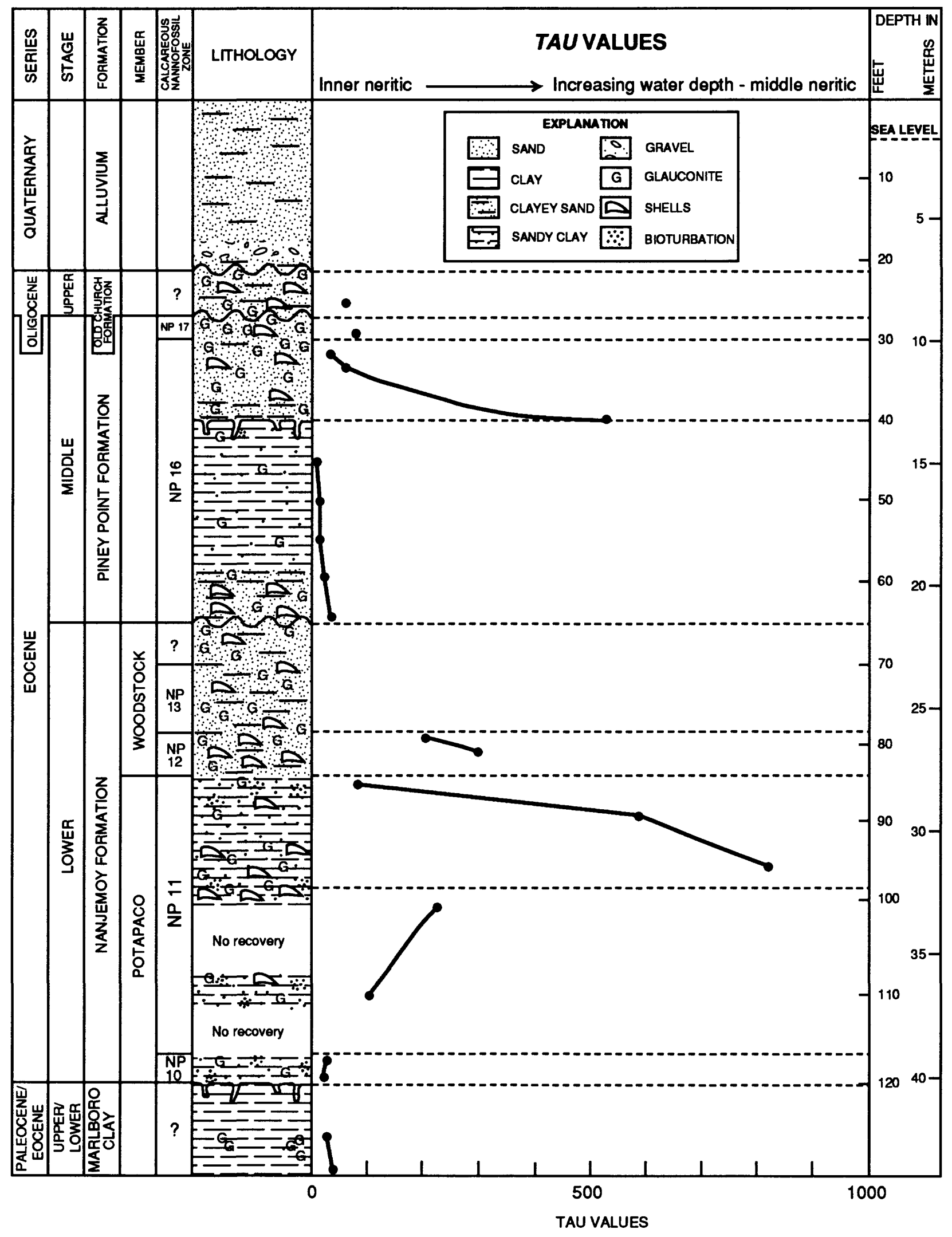

Figure 2. Stratigraphic column of Putneys Mill corehole and tau values (number of benthic foraminiferal species $X$ planktonic percentage). Dashed lines represent cycle boundaries. 


\section{LOCATION AND METHODS}

The Putneys Mill corehole was drilled at Putneys Mill on the southern (right) bank of the Pamunkey River. The corehole is located at latitude 37'36'18" N, longitude $77^{\circ} 05^{\prime} 35^{\prime \prime} \mathrm{W}$ in New Kent County, Virginia in the Tunstall $7 \frac{1}{2} 2$-minute quadrangle. The top of the corehole is approximately $5 \mathrm{ft}$ above sea level. Dennis W. Duty and Donald G. Queen of the Branch of Eastern Regional Geology of the U.S. Geological Survey drilled the corehole on November 2729, 1979. Laurel M. Bybell, Lucy E. Edwards, and Thomas G. Gibson were the geologists on the site. Most cores were taken by a 4-ft-long split-spoon barrel that was inserted through the middle of hollow stem auger sections (appendix 1). Five-foot auger sections were used during drilling. After the 4-ft-long split-spoon core was taken ahead of the auger stem, a 5-ft auger section was added, and the auger stem was run down to working height. The 5-ft augered interval extended $1 \mathrm{ft}$ beyond the end of the preceding 4- $\mathrm{ft}$ split-spoon core, resulting in the noncoring of the bottom $1 \mathrm{ft}$ of each auger run. Thus, the core consists primarily of 4 -ft split-spoon runs followed by 1 - $\mathrm{ft}$ nonsampled intervals. Near the bottom of the hole, a 5- and a 6 - $\mathrm{ft}$ interval were not sampled because of time constraints. The two lowermost split-spoon cores were $6 \mathrm{ft}$ in length (appendix 1). No electric logs were made of the corehole.

Foraminiferal samples were washed over a $63 \mu \mathrm{m}$ screen. Foraminifera were concentrated from washed samples, if necessary, by flotation in a bromoform and acetone mixture or a soap solution. The samples were divided by the use of a small microsplitter, and an aliquot of 300 or more benthic specimens was examined. The benthic foraminifera were identified to the species level, and the total number of planktonic specimens in the aliquot was counted.

Calcareous nannofossil slides were prepared using standard settling techniques and were examined with a Zeiss Photomicroscope III.

\section{LITHOLOGIC UNITS}

The Paleogene formations penetrated in the Putneys Mill corehole include the upper part of the Marlboro Clay (probable latest Paleocene or possible earliest Eocene age), the Nanjemoy Formation (early Eocene age), the Piney Point Formation (middle Eocene age), and the Old Church Formation (probable late Oligocene age). The material from a depth of $21 \mathrm{ft}$ to the surface consisted of alluvium. A lithic summary of the corehole is given below, and a detailed on-site description of the core is found in Appendix 1.

\section{Marlboro Clay}

The Marlboro Clay consists of $9.5 \mathrm{ft}$ of clay that was penetrated from the total depth of the corehole at $130 \mathrm{ft}$ to $120.5 \mathrm{ft}$. The Marlboro is a slightly silty, massively bedded clay. The lower part contains scattered pods of glauconitic sand and a few poorly preserved shells. There is a sharp upper contact of the Marlboro Clay with the overlying Nanjemoy sandy clay; this disconformable relationship appears to be present both in outcrop and in subsurface sections in 
Virginia and Maryland (Glaser, 1971; Gibson and others, 1980; Ward, 1985; Weems, 1986; Mixon and others, 1989). The uppermost $1 \mathrm{ft}$ of the Marlboro is highly burrowed here, as elsewhere, and the burrows are filled with sediment from the overlying Nanjemoy Formation. The lower boundary of the Marlboro was not penetrated in this corehole.

In the Putneys Mill corehole, the upper $2 \mathrm{ft}$ of the Marlboro are gray in color, but the remainder is reddish brown. The upper and lower beds of the Marlboro typically are gray, and the middle part typically is reddish brown (Glaser, 1971). Gibson and others (1993) proposed that the color difference between the red Marlboro beds and the gray coeval beds of the lower Manasquan Formation in New Jersey may reflect differing oxidation levels in the oceanic waters. The reddish colors suggest somewhat higher oxidation levels, possibly because they were deposited in shallower, more highly oxygenated environments than the gray clays that probably represent deposition in somewhat deeper, less oxygenated environments. The red and gray beds within the Marlboro itself also may reflect differing oxidation levels at the time of deposition.

\section{Nanjemoy Formation}

The Nanjemoy Formation consists of $55.5 \mathrm{ft}$ of sediments that extend from 120.5 to 65 $\mathrm{ft}$. The lower and middle parts of the Nanjemoy are dark-olive to dark-green, bioturbated, very fine to fine sandy clay. Glauconite varies from 5 to 15 percent, and there are some black phosphate grains. The beds usually contain sparse, scattered clam shells, but there are some thin intervals that contain numerous clam shells. Shells become less abundant in the lower part of the formation. Pyrite nodules and carbonaceous debris occur in the lower part. The upper part of the Nanjemoy Formation is coarser grained than the lower part and contains dark-green, clayey, very fine sand. The sand beds have a highly bioturbated fabric, contain from 10 to 30 percent glauconite, and have abundant mica and abundant scattered clam shells. The Nanjemoy has a highly burrowed lower contact with the underlying Marlboro and an undulating upper contact with the Piney Point.

Based upon sections exposed along the Potomac River, Clark and Martin (1901) divided the Nanjemoy Formation into two members. The lower or Potapaco Member was distinguished by its clayey character. The upper or Woodstock Member was distinguished by glauconitic sands that are less argillaceous than the Potapaco beds. These members have been recognized in numerous places in southern Maryland and northern Virginia (Glaser, 1971; Gibson and others, 1980; Ward, 1985; Mixon and others, 1989).

The two lithologies present in the Nanjemoy in the Putneys Mill corehole, a lower more clayey unit and an upper sandier unit (fig. 2), are similar to the two lithologies found in this formation's type area along the Potomac River. In addition to the lithologic similarities between the Potomac and Pamunkey River areas, there also is an age similarity between the two lithofacies in the two areas. For example, in the Putneys Mill corehole, the clayey beds are placed in early Eocene calcareous nannofossil Zones NP 10 and NP 11 (fig. 2), and the overlying sandy beds are placed in early Eocene Zones NP 12 and NP 13 (see Biostratigraphy section below). Bybell and Gibson (1991) and Gibson and Bybell (1991) assigned the clayey beds of the Potapaco Member in outcrop along the Potomac to Zones NP 10 and NP 11 and the sandy beds of the Woodstock Member to Zones NP 12 and NP 13. Therefore, the two members 
appear to be recognizable and also coeval between the two areas. The continuation of the two lithologies across the southern and central part of the Salisbury embayment reflect similar sedimentary conditions in this area with regard to type of sediment influx, sea level and (or) distance from shore, and energy level in the basin.

Ward (1985) recognized a series of four beds within the Potapaco Member in northern Virginia. Mixon and others (1989) recognized four fining-upward sequences in the Potapaco Member, but the relationship of their four units to those of Ward is somewhat uncertain. The relationship of either of these four-fold subdivisions of the Potapaco to the three depositional cycles that we identify in this member in the Putneys Mill corehole is uncertain and needs further study.

We recognized three depositional cycles in the Potapaco strata in the Putneys Mill corehole and one to possibly two cycles in the Woodstock Member (fig. 2). The boundaries of these cycles, as well as those identified in the younger strata, can be recognized by one or more of the following criteria. Some of the criteria are readily visible, while others are much more subtle and involve a detailed examination of the beds and (or) their calcareous microfossils. The criteria may show an abrupt change or a gradational change over a short distance. They include 1) a readily visible surface that may be undulating or heavily burrowed, 2) a change in lithology that may vary from abrupt to gradational, 3) a change in the amount of glauconite, 4) the presence of coarse sand and (or) fine gravel, 5) the presence of phosphate pebbles and (or) a significant amount of bone or wood fragments, 6) a biostratigraphic change from one calcareous nannofossil zone to another that has been recognized in surrounding areas to represent a disconformity or a flooding surface, 7) the presence of an increased amount of clay in the uppermost part of a unit that is associated with a reduced diversity calcareous nannofossil or foraminiferal assemblage, 8) the presence of a recrystallized calcareous nannofossil or foraminiferal assemblage or the complete absence of either or both groups in the uppermost part of a unit, 9) an abrupt change in paleobathymetry that is indicated by changes in the composition of the benthic foraminiferal assemblage and (or) the proportion of the planktonic component, particularly when this is associated with a change in the calcareous nannofossil zone present at the time of paleobathymetric change, and 10) an abrupt change in the benthic foraminiferal species with no corresponding significant change in paleobathymetry.

The Nanjemoy Formation is thinner in the Putneys Mill corehole than in the coreholes in northern Virginia and southern Maryland. A thickness of $55.5 \mathrm{ft}$ for the Nanjemoy at Putneys Mill compares with thicknesses of $123 \mathrm{ft}$ at Oak Grove (Gibson and others, 1980), $90.7 \mathrm{ft}$ at Haynesville (Mixon and others, 1989), and $161 \mathrm{ft}$ at Solomons Island (Gibson and Bybell, 1994). Deposits representing all calcareous nannofossil zones present in the Nanjemoy in the central and southern Salisbury embayment also are found at Putneys Mill, so the relatively thin section present here apparently is a result of general thinning of the unit or erosional removal of parts of the formation rather than simply an erosional truncation of the upper part (fig. 2). In fact, Zone NP 13, which is present at Putneys Mill, is not reported in the much thicker section at Oak Grove. 


\section{Piney Point Formation}

The Piney Point Formation consists of $38 \mathrm{ft}$ of sediments that were penetrated from 65-27 $\mathrm{ft}$. Two lithologies are present in this formation. Sand dominates the lowest part of the formation (65-60 ft) and also the upper part (40-27 ft), while clay is the dominant lithology in the middle part (60-40 ft). The upper and lower sands are dark green, fine, clayey, and have a highly bioturbated fabric. The sand from 38 to $30 \mathrm{ft}$ has a calcareous matrix. The beds contain moderate to high amounts of glauconite (10-70 percent) and moderate to abundant mollusk shells. The sand of the uppermost $3 \mathrm{ft}$ of the Piney Point Formation (30-27 ft), is darker in color and much more glauconitic than the immediately underlying sand.

The middle part of the formation is composed of light- to medium-gray clay. Some parts of the clay are massively bedded and have a bioturbated fabric, while other parts contain thin laminae of silt to very fine sand with fine shell fragments. Interbedded sandy clay and clayey sand beds are present at the base of the clay unit. The Piney Point has an undulating lower contact with the underlying Nanjemoy Formation; the upper contact with the overlying Old Church Formation was not recovered at Putneys Mill.

Three cycles are recognized in the Piney Point Formation (fig. 2). A clay lithofacies dominates the lowest cycle. Ward (1984) and Strickland (1984) did not mention any thick clay intervals in their descriptions of the outcropping Piney Point beds along the Pamunkey River. As their descriptions are based upon a composite of many small exposures along the river banks, it is possible that this clay interval was not exposed or was overlooked. Other possibilities for the absence of this clay lithofacies in their sections include a rapid downbasin lithofacies change from sand in the outcrop belt to clay in the shallow subsurface or the erosion of this clay unit from the more westerly, higher elevation exposures of the outcrop area along the Pamunkey River. There is no clay interval in the Piney Point Formation to the north in the Haynesville (Mixon and others, 1989) or Solomons Island (Gibson and Bybell, 1994) coreholes. In both coreholes the Piney Point is composed of fine to coarse sand interbedded with carbonatecemented sandstone and moldic limestone.

A burrowed surface separates the lower clay cycle from the overlying glauconitic sand cycle. The second cycle and the third or uppermost cycle of the Piney Point are in different calcareous nannofossil zones; accompanying this age difference is a subtle lithologic change to considerably more glauconite and a less calcareous matrix in the uppermost cycle.

The thickest cored section of Piney Point is in the Haynesville corehole, where it is 55 $\mathrm{ft}$ thick (Mixon and others, 1989). The formation is $45 \mathrm{ft}$ thick in the Solomons Island corehole (Gibson and Bybell, 1994), a thickness similar to the $38 \mathrm{ft}$ found at Putneys Mill.

\section{Old Church Formation}

Six feet of the Old Church Formation were penetrated (27-21 ft) in the corehole. The lithology consists of medium- to dark-green, clayey, very fine to fine sand that is massively bedded. The unit contains 10-20 percent glauconite and abundant mollusk shells. The lowermost $0.5 \mathrm{ft}$ that was recovered is a somewhat coarser sand that has 20 percent glauconite; Ward (1985) regarded the increased glauconite as a reworked component from the underlying 
highly glauconitic bed of the Piney Point. The lower contact with the underlying Piney Point Formation was not recovered in the Putneys Mill corehole. The upper contact with the overlying alluvium is disconformable.

The Old Church Formation is $3 \mathrm{ft}$ thick at its type locality along the Pamunkey River (Ward, 1985). The formation is thin in most known sections in Virginia and southern Maryland. The Old Church Formation is absent in the Oak Grove (Gibson and others, 1980) and Solomons Island (Gibson and Bybell, 1994) coreholes, but $4.1 \mathrm{ft}$ were recovered in the Haynesville corehole (Mixon and others, 1989).

\section{BIOSTRATIGRAPHIC ZONATION}

Calcareous nannofossils and planktonic foraminifers were examined from the Putneys Mill corehole. Most of the 75 core samples contained calcareous nannofossils, and they could be placed within specific calcareous nannofossil zones, thus giving a detailed age resolution to the strata in the corehole (fig. 3). Biostratigraphic placement of the Putneys Mill strata by the use of planktonic foraminiferal zonations was limited because most samples contained only a few planktonic foraminifers, many of which were immature specimens of long-ranging taxa. Very few samples contained diagnostic planktonic species.

\section{Calcareous Nannofossil Zonal Indicators}

The Putneys Mill core was dated by means of the zonation of Martini (1971), and the following species define the zonal horizons. FAD indicates a first appearance datum, and LAD indicates a last appearance datum.

top Zone NP 16 - LAD of Chiasmolithus solitus (middle Eocene) top Zone NP 15 - LAD of Rhabdosphaera gladius (middle Eocene) base Zone NP 15 - FAD of Nannotetrina fulgens (middle Eocene) base Zone NP 14 - FAD of Discoaster sublodoensis (early Eocene) top Zone NP 12 - LAD of Rhomboaster orthostylus (early Eocene) base Zone NP 12 - FAD of Discoaster lodoensis (early Eocene) top Zone NP 10 - LAD of Rhomboaster contortus (early Eocene) base Zone NP 10 - FAD of Rhomboaster bramlettei (early Eocene) base Zone NP 9 - FAD of Discoaster multiradiatus (late Paleocene) 


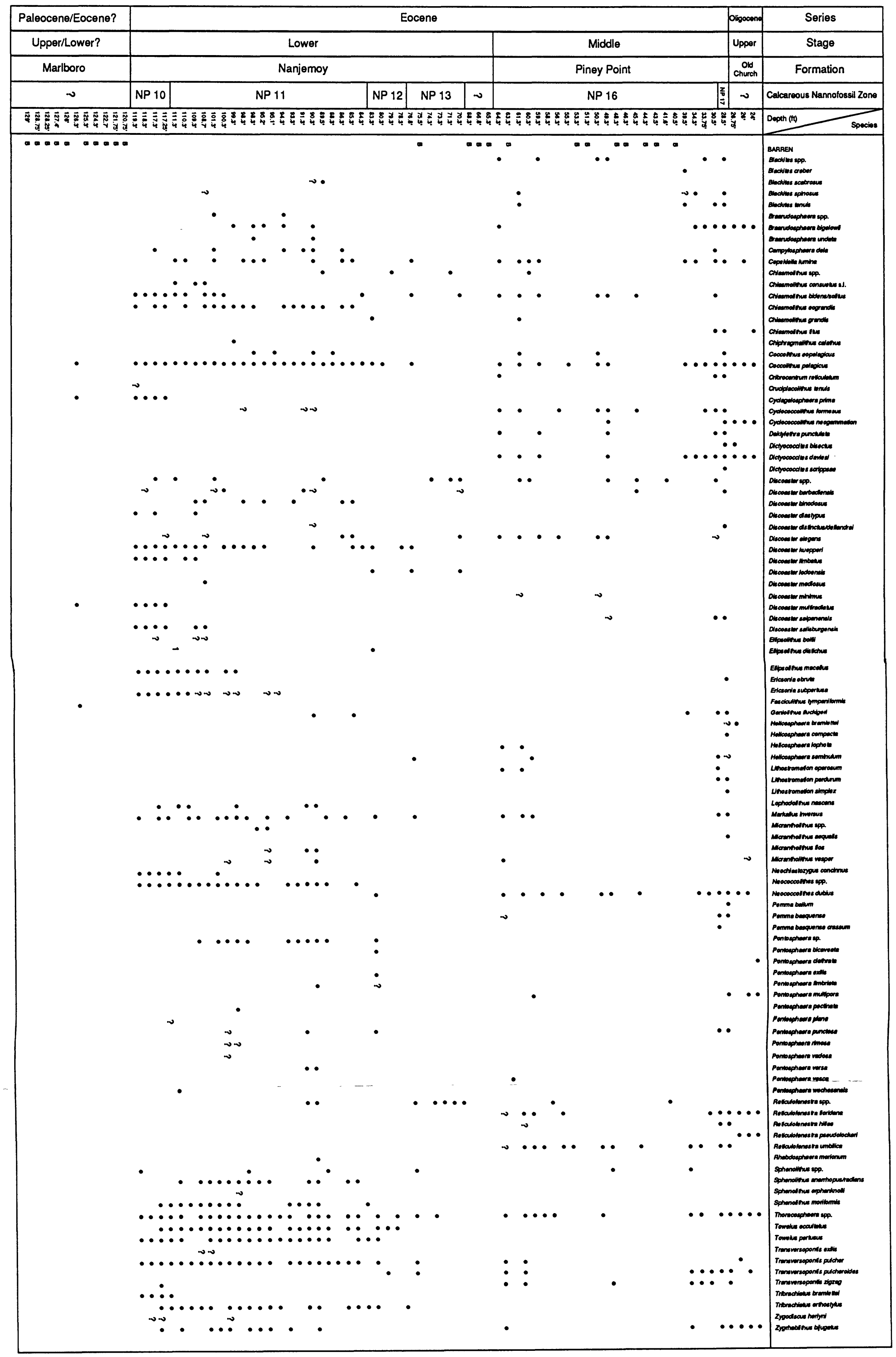

Figure 3. Distribution of calcareous nannofossil species in Putneys Mill samples. 
Calcareous nannofossil occurrences for the Putneys Mill corehole are found in Figure 3. The following list gives the approximate length of relevant NP Zones as taken from Berggren and others (1985):

\author{
Zone NP $16-3.1 \mathrm{my}$ \\ Zone NP $15-4.6 \mathrm{my}$ \\ Zone NP $14-2.6$ my \\ Zone NP $13-1.1 \mathrm{my}$ \\ Zone NP $12-1.5$ my \\ Zone NP $11-1.4$ my \\ Zone NP $10-1.2 \mathrm{my}$ \\ Zone NP $9-1.4 \mathrm{my}$
}

\title{
Marlboro Clay
}

Frederiksen and others (1982) considered the Marlboro Clay in Virginia to be either latest Paleocene or earliest Eocene in age. Using calcareous nannofossil data, the Marlboro Clay in the Putneys Mill corehole is most likely late Paleocene (upper Zone NP 9) in age. Eleven samples were examined from the Marlboro Clay, and ten were barren of calcareous nannofossils. One sample at $126.3 \mathrm{ft}$, near the center of the recovered section, contained a sparse assemblage of four species, including the following. Discoaster multiradiatus has its FAD at the base of Zone NP 9 and becomes extinct within Zone NP 11 (Martini, 1971). Fasciculithus tympaniformis has a FAD at the base of Zone NP 5 and a LAD in the lowest part of Zone NP 10 (Gibson and others, 1993; Bybell and Self-Trail, 1995). Cyclagelosphaera prima does not occur above Zone NP 10. Therefore, this sample could range in age from Zone NP 9 in the late Paleocene to the lower part of Zone NP 10 in the early Eocene. The absence of Rhomboaster bramlettei (its FAD defines the base of Zone NP 10; was Tribrachiatus bramlettei; see Bybell and Self-Trail, 1995 ), a species which is moderately resistant to dissolution, may indicate that this sample is within Zone NP 9 and not within Zone NP 10. This is not very strong evidence, due to the fact that the calcareous nannofossil assemblage is so sparse. However, a sample from the middle part of the Marlboro Clay section in the Waldorf, Maryland, corehole (fig. 1), which contains 12 calcareous nannofossil species, also does not contain Rhomboaster bramlettei, and this sample has been placed fairly reliably in Zone NP 9. Therefore, placement of the Marlboro Clay within Zone NP 9 at Putneys Mill seems appropriate. The Aquia Formation, which underlies the Marlboro Clay in much of Maryland and Virginia, has a thick section of Zone NP 9 in its upper part. It therefore seems more reasonable to place the overlying Marlboro Clay within the upper part of Zone NP 9 rather than in the lower part of Zone NP 9. 


\section{Nanjemoy Formation}

Thirty-five samples were examined from the Nanjemoy Formation in the Putneys Mill core. Most of these could be placed within an individual calcareous nannofossil zone. The entire Nanjemoy in this corehole is early Eocene in age and extends from upper Zone NP 10 into Zone NP 13.

The basal Nanjemoy sample at $119.3 \mathrm{ft}$ can be placed in the upper half of Zone NP 10, based on the presence of Rhomboaster bramlettei (FAD defines the base of Zone NP 10) and Discoaster diastypus (FAD occurs near the middle of Zone NP 10), and the absence of Rhomboaster orthostylus (FAD in the upper fourth of Zone NP 10; was Tribrachiatus orthostylus; see Bybell and Self-Trail, 1995). The FAD of Rhomboaster contortus (was Tribrachiatus contortus, see Bybell and Self-Trail, 1995) normally occurs at approximately the same interval as $D$. diastypus (mid Zone NP 10), but $R$. contortus is absent in the Putneys Mill corehole. See Perch-Nielsen (1985), Gibson and others (1993), and Bybell and Self-Trail (1995) for additional discussion of these species and their ranges. Elsewhere in Virginia and Maryland, a part of the Nanjemoy that is older (lower Zone NP 10) than any in this core is present. For example, in the Oak Grove corehole in Virginia (Gibson and others, 1980) and the Solomons Island (Gibson and Bybell, 1994; Bybell and Self-Trail, 1995) and Waldorf (L.M. Bybell, unpub. data) coreholes in Maryland (fig. 1), there are about 20 feet of sediments in lower Zone NP 10 that contain $R$. bramlettei, but do not contain $R$. contortus, $D$. diastypus, or $R$. orthostylus. The sample at $117.3 \mathrm{ft}$ in the Putneys Mill core, which is two feet above the base of the Nanjemoy, does contain $R$. orthostylus, which indicates placement within the upper fourth of Zone NP 10. The top of Zone NP 10 is defined by the LAD of Rhomboaster contortus, but this species is not present in the Putneys Mill corehole. However, the LAD of Rhomboaster bramlettei, which occurs only slightly before the LAD of $R$. contortus, can be used to approximate this boundary. Rhomboaster bramlettei last occurs at $117.3 \mathrm{ft}$, and this is considered to be the highest Zone NP 10 sample.

The absence of the lower Zone NP 10 depositional cycle in the Putneys Mill corehole could either be a result of nondeposition of beds of this age or erosional removal. From North Carolina to New Jersey in the Atlantic Coastal Plain, Gibson and others (1992) showed that there is common and widespread erosional removal of parts of or entire depositional cycles from Paleogene deposits. To date, there has been no documentation of the paleogeography of the southern part of the Salisbury embayment that would allow one to determine whether structural highs were present near Putneys Mill that could have prevented deposition during the earliest Eocene, a time of relatively high sea level stand (Gibson and others, 1993).

There is a thick Zone NP 11 portion in the Putneys Mill corehole from $111.3 \mathrm{ft}$ to 84.3

$\mathrm{ft}$. The FAD of Discoaster lodoensis, which defines the base of Zone NP 12, first occurs at $83.3 \mathrm{ft}$. Zone NP 12 sediments extend up to $78.3 \mathrm{ft}$, where Rhomboaster orthostylus last occurs. There are only five feet of Zone NP 12 sediments in the Putneys Mill core, yet according to Berggren and others (1985) (see above), Zones NP 11 and NP 12 are very similar in duration (1.4 and $1.5 \mathrm{my}$ ). In the Putneys Mill core, Zone NP 11 sediments are $22 \mathrm{ft}$ thicker than Zone NP 12 sediments, and it appears that much of Zone NP 12 sediments are missing, probably due to erosion. The missing sediments could be a reflection of an unconformity between the Potopaco and Woodstock Members. Zone NP 13 sediments extend from 76.8 to $70.3 \mathrm{ft}$. 
Discoaster sublodoensis (its FAD marks the base of Zone NP 14) does not occur in this core. The uppermost portion of the Nanjemoy Formation from $68.3 \mathrm{ft}$ to $65.3 \mathrm{feet}$ is barren of calcareous nannofossils and cannot be dated, although it is most likely still within Zone NP 13, based upon the age of the upper part of the Nanjemoy Formation in other coreholes, such as at Solomons Island, which has the thickest known section (Gibson and Bybell, 1994). Zones NP 14 and NP 15 are unknown in this region.

The Nanjemoy Formation is more than twice as thick in the Oak Grove corehole (121 $\mathrm{ft}$ ) as in the Putneys Mill corehole (55 ft). This difference in thickness is striking because the Putneys Mill corehole contains beds younger (Zone NP 13) than any found in the Oak Grove corehole (top is in Zone NP 12). Thus, subsequent erosional truncation of the upper part of the formation is not the cause for the difference in thickness. The thickness difference could be a result of paleogeographic constraints on the deposition. Because all biostratigraphic zones that occur in the Nanjemoy in the Oak Grove corehole also are represented in the Nanjemoy in Putneys Mill corehole, long-term topographic highs do not appear to be controlling primary depositional features in the Putneys Mill area. Differences in rates of sedimentation may be a controlling factor, but complete cycle thickness will need to be compared among the various areas. We suspect that erosional removal of depositional cycles from within individual NP zones is a likely cause for much of the thickness variations. As discussed above, the lower depositional cycle of Zone NP 10 that is found in the Oak Grove corehole and other Maryland coreholes is absent from the Putneys Mill corehole. Gibson and Bybell (in press) documented the presence of four depositional cycles within Zone NP 11 in the Oak Grove corehole. In the more downbasin Solomons Island corehole, however, where one might expect as complete or even more complete sections, only one of the four cycles is present (Gibson and Bybell, 1994). The Solomons Island Zone NP 11 section is much thinner than that found in the Oak Grove corehole because of the absence of three of the four cycles, and it is thinner than that found in the Putneys Mill corehole where two cycles are present. The Solomons Island corehole is located downbasin of the Oak Grove corehole, so deposition of all four cycles would be expected in both areas. The missing three cycles at Solomons Island probably were removed by erosion.

Sedimentation rates certainly vary in different parts of the Atlantic Coastal Plain, and more upbasin sites are likely to receive greater sedimentation within a given time interval in this relatively sediment starved basin. The more downbasin areas commonly have a more condensed, thinner section for any given time interval (Gibson and others, 1992). The complete absence of some depositional cycles in various parts of the basin, however, suggests that erosional removal of cycles is common and widespread. Different cycles may be removed from different areas. Slight to moderate differences in the original sedimentary thickness of a cycle will account for some of the thickness differences between areas within the Salisbury embayment, but we strongly suggest that the major cause of the variations is local erosional removal of parts or all of various cycles. 


\section{Piney Point Formation}

On the basis of calcareous nannofossil data, the Piney Point Formation in the Putneys Mill core is middle Eocene in age (Zones NP 16 and NP 17). Twenty-four samples were examined from this formation for their calcareous nannofossil content. Unlike the Nanjemoy samples, one-third of the Piney Point samples were barren of calcareous nannofossils. These eight barren samples are from four separate intervals within the lower sedimentary cycle of the Piney Point (see Paleoenvironments section). The alternating fossiliferous and barren intervals indicate that there may have been significant fluctuations in the sedimentary environment during deposition of the Piney Point Formation.

The basal Piney Point Formation sample at $64.3 \mathrm{ft}$ was placed in Zone NP 16 due to the presence of Cribrocentrum reticulatum (FAD in Zone NP 16) and Chiasmolithus solitus (LAD at the top of Zone NP 16). The highest Zone NP 16 sample (last sample to contain C. solitus) is at $30.5 \mathrm{ft}$. The youngest Piney Point Formation sample is from $28.5 \mathrm{ft}$ and is placed in Zone NP 17, based on the absence of Chiasmolithus solitus (LAD at the top of Zone NP 16) and the presence of Helicosphaera compacta (FAD just below the base of Zone NP 17). This sample is within the uppermost very glauconitic sand unit of the Piney Point.

\section{Old Church Formation}

Three calcareous nannofossil samples were examined from the Old Church Formation in the Putneys Mill core. The samples contain a calcareous nannofossil assemblage that indicates a probable late Oligocene age. There have been questions in the past whether the Old Church Formation is latest Oligocene or earliest Miocene in age, but DiMarzio (1984), Edwards (1984), and Frederiksen (1984) believed the Old Church to be no younger than latest Oligocene in age. Poag (1989) gave a middle to late Oligocene age for the Old Church strata in the Haynesville corehole. The current authors agree that the Old Church Formation cannot be Miocene in age based on the presence of Zygrhablithus bijugatus and Dictyococcites bisectus in the Putneys Mill core. Neither of these species occurs above the youngest Oligocene calcareous nannofossil Zone NP 25 (Perch-Nielsen, 1985).

\section{RELATIONSHIP OF PUTNEYS MILL COREHOLE STRATA}

In addition to the Putneys Mill corehole, Eocene and Oligocene strata have been studied in two other coreholes in Virginia, the Oak Grove corehole (Gibson and others, 1980) and the Haynesville corehole (Mixon and others, 1989) (fig. 1). A correlation chart of these coreholes (fig. 4) shows the large time periods that are not presently represented by strata in this area. This non-representation is a result both of non-deposition during some time periods and subsequent erosion of deposits that were originally deposited during other time periods.

In the Oak Grove corehole, Miocene strata rest upon the Nanjemoy Formation, and widespread erosional truncation of sequences, such as that suggested by Gibson and others (1992), probably removed the Piney Point and Old Church Formations in this area. 


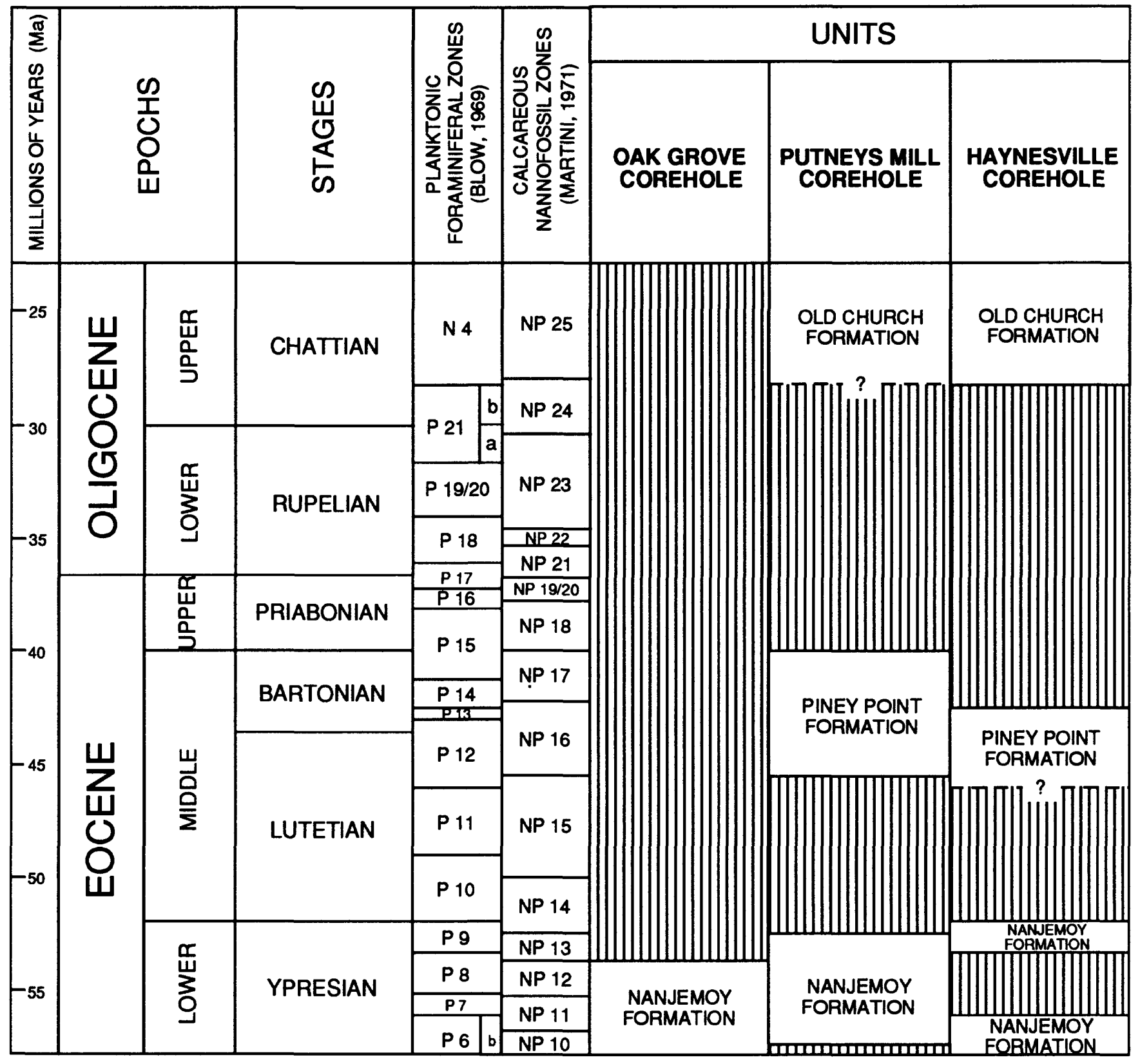

Figure 4. Correlation chart of Eocene and Oligocene strata in Putneys Mill, Oak Grove (Gibson and others, 1980), and Haynesville (Mixon and others, 1989) coreholes. Time scale from Berggren and others (1985). 
The Chickahominy Formation of late Eocene age is not found in any of the three coreholes, but it is present in the subsurface a short distance to the east of the Putneys Mill and Haynesville coreholes (Gibson, 1970). This unit most likely also was erosionally removed from these areas.

Probably the biggest difference between the three coreholes is the large disconformity shown in the middle of the Nanjemoy Formation in the Haynesville corehole. Calcareous nannofossils were used for biostratigraphic zonation of the Oak Grove and Putneys Mill coreholes, but planktonic foraminifera were utilized in the Haynesville corehole (Poag, 1989). As mentioned above, diagnostic planktonic foraminifera are not present in many samples, whereas most samples can be placed into the calcareous nannofossil zonation. Deposits placed in calcareous nannofossil Zones NP 11 and 12 are present in all coreholes studied in Virginia and Maryland (Gibson and others, 1980; Gibson and Bybell, 1994; Laurel M. Bybell, unpub. data). However, deposits belonging to the upper part of Zone NP 11 and all of Zone NP 12 are not recognized in the Haynesville corehole (Poag, 1989). This biostratigraphic placement is based upon the occurrence of one species, Acarinina aspensis, in one sample that Poag considered indicative of planktonic foraminiferal zone $\mathrm{P} 9$. This results in a placement of strata of zone $\mathrm{P} 9$ sitting upon strata of zone $\mathrm{P} 6 \mathrm{~b}$, with a resultant disconformity. However, Edwards (1989) reported from these "zone P 9" strata a succession of dinoflagellate taxa that make their usual succession in Virginia and Maryland in what Poag considers the missing interval. The important dinoflagellates include Wetzeliella varielongituda, which usually has its first occurrence in the middle of Zone NP 11 and Kisselovia coleothrypta, which has its first occurrence in the lower part of Zone NP 12 (Lucy Edwards, personal commun., 1991). The successive appearance of these taxa suggests strongly that the "disconformity" is actually represented in the sedimentary record in the Haynesville corehole.

\section{PALEOENVIRONMENTS}

The Paleogene strata consist primarily of bioturbated, glauconitic clayey sands and sandy clays, except for the Marlboro Clay and the clay unit within the Piney Point Formation, and there are few environmental interpretations that can be made on the basis of the lithologic characteristics. The following paleoenvironmental analyses are based primarily upon foraminiferal assemblages.

The most valuable criteria for environmental interpretations include: 1) the generic and specific composition of the foraminiferal assemblages, 2) the species diversity and species dominance of the assemblages, and 3) the planktonic/benthic ratio of the assemblages. A generalized paleobathymetric history of the Paleogene formations in the Putneys Mill corehole is constructed from the foraminiferal assemblages. Paleobathymetric trends are shown (fig. 2) by use of the tau index (Gibson, 1988). Tau values are the mathematical product of the number of benthic foraminiferal species times the percentage of planktonic specimens in the total foraminiferal assemblage in a sample.

Buzas and Gibson (1969) and Gibson and Buzas (1973) showed that although the number of benthic species exhibits a general increase from inner neritic depths into abyssal depths along the U.S. Atlantic margin, the increase is not necessarily a continually progressive one. The number of species in a sample generally increases from inner neritic to outer neritic depths, but the number of species in samples from the upper continental slope may be lower than those 
found on outer parts of the shelf. An increase in the number of species begins again on the middle and lower parts of the slope, and this increase continues into abyssal regions. This pattern places limits on the use of the number of species for interpretation of slope paleoenvironments.

The planktonic proportion of the foraminiferal assemblage, however, generally continues to increase across the shelf and through upper and middle slope environments (Grimsdale and Van Morkhoven, 1955; Gibson, 1989). Gibson (1988) proposed the index tau, which is the product of the number of benthic species times the percentage of planktonic specimens in the total foraminiferal assemblage of a sample. The values of this index increase across the shelf, down the slope, and into abyssal regions. Gibson (1988, fig. 11) showed that Parker's (1954) data from the northeastern Gulf of Mexico region gives tau values of 1-100 in waters less than $130 \mathrm{ft}$ deep. The tau values continue a general increase with increasing depth and reach 10,000 in water depths around 3,000 ft. There is no exact correlation between any particular tau value and a particular water depth, but various depth interval categories and paleobathymetric trends can be recognized. The tau values also may vary between different sedimentary basins because of particular environmental conditions, but the plotting of tau values through a section in a single sedimentary basin normally follows the paleobathymetric trends (fig. 2).

Because the species, as well as genera, composing the foraminiferal assemblages vary both in their proportions and in their presence or absence with changes in bathymetry and other environmental complexes, the taxonomic composition of the assemblages is an additional valuable tool for the interpretation of the paleoenvironmental changes. Van Morkhoven and others (1986), Olsson and Wise (1987), and Poag (1989) discussed the paleoenvironmental significance of Paleocene and Eocene taxa, many of which occur in the Solomons Island deposits. Gibson is preparing a much more extensive paleontologic manuscript that contains detailed lists and illustrations of the foraminiferal taxa from the Paleogene formations in the Putneys Mill corehole and discussions of their paleoenvironmental significance.

The generic composition of the foraminiferal assemblage, the low to moderate number of species, the relatively small percentage of planktonic specimens in most samples, and the relatively low tau values suggest that most of the Paleogene beds in the Putneys Mill corehole were deposited in inner neritic environments. Several somewhat deeper water pulses of inner middle neritic depths, however, are present in the Paleogene strata as discussed below.

\section{Marlboro Clay}

The Marlboro Clay usually has been considered to represent deposition in marginalmarine, brackish-water to very shallow marine, possibly tidal flat conditions (Nogan, 1964; Glaser, 1971; Gibson and others, 1980). Most Marlboro sections studied by these workers do not contain foraminifers; the relatively few beds in the Marlboro that do contain foraminifers usually contain only agglutinated species. In the modern ocean, entirely agglutinated assemblages are most commonly found in brackish waters of moderate to low salinity, or in very deep oceanic environments below the carbonate compensation depth. Nogan (1964) and Gibson and others (1980) concluded that the Marlboro represented brackish water deposition, based on 
the presence of only agglutinated foraminifers, the low diversity and composition of the dinoflagellate assemblages, and the presence of freshwater alga.

Recently, the current authors examined two Marlboro samples in the Putneys Mill corehole, as well as one Marlboro sample in the Waldorf corehole in Maryland, that contain calcareous foraminifers. The same calcareous benthic species occur in the two Marlboro samples from the Putneys Mill corehole as in the underlying Aquia Formation and the overlying Nanjemoy Formation, both of which were deposited in inner to inner middle neritic environments. The Marlboro samples in the Putneys Mill corehole, however, are strongly dominated by Pulsiphonina prima, and this species composes 76 percent and 81 percent of the benthic assemblages. Although this species occurs in the more clayey portions of the Aquia and Nanjemoy Formations, it comprises less than five percent of the foraminiferal assemblage in those units. It comprises similar proportions in the assemblages from the lower Eocene Bashi and Hatchetigbee Formations in Alabama (T.G. Gibson, unpub. data). This species' occurrence is highest in dark-colored, clay-rich beds that commonly contain carbonaceous debris, and it appears to be tolerant of high-productivity/low-oxygen environments. This genus has not been documented in marginal-marine environments.

Gibson and others (1993) found high-productivity/low-oxygen environments in the latest Paleocene/earliest Eocene (uppermost Zone NP 9/lowermost Zone NP 10) deposits in New Jersey, and these beds contained foraminiferal assemblages in which $P$. prima comprised between 15 and 37 percent of the benthic assemblage. The very high proportion of this species in the Putneys Mill samples similarly demonstrates that during the deposition of this Paleocene/Eocene boundary clay, low-oxygen environments extended southward in the Salisbury embayment as far as central Virginia.

The two productive samples in the Putneys Mill corehole have moderately low species diversities of 15 and 17 species. The species diversity values of the two samples are typical of inner neritic depositional environments (Gibson and Buzas, 1973). The two Marlboro assemblages in the Putneys Mill corehole contain low planktonic foraminiferal components of 1.6 and 2.6 percent, also characteristic of shallow, inner neritic environments (Gibson, 1989). The planktonic foraminiferal proportions are higher, however, than those found in almost all marginal-marine environments. The tau values of 26 and 39 (fig. 2) also suggest inner neritic environments.

Therefore, in contrast to the earlier interpretations of the Marlboro Clay as representing marginal-marine environments, the foraminiferal assemblages in the Putneys Mill corehole suggest that this formation was deposited in a mud-rich, inner neritic environment with water depths of 60-120 ft. This mud-rich, low-oxygen environment was present in neritic water depths throughout the Salisbury embayment at the same time (latest Paleocene) as shown by deposits representing inner neritic depths in the Putneys Mill corehole, inner to middle neritic environments in the Waldorf corehole (Gibson and Bybell, in press), and middle to outer neritic environments in southwestern New Jersey (Gibson and others, 1993). 


\section{Nanjemoy Formation}

The assemblage in the two samples from the Zone NP 10 cycle suggests deposition in inner neritic water depths of $20-40 \mathrm{~m}$. The diversity is relatively low (12 to 16 species), the planktonic percentage is less than 2 , and there are low tau values of 18 and 27 . Lowoxygen/high-productivity conditions also were present during this time because the assemblage is dominated by Lenticulina, Pyramidina, Epistominella, Fursenkoina, and Anomalinoides.

The lower cycle in Zone NP 11 was deposited in shallower water than the upper cycle. Foraminiferal specimens in the upper sample of this lower cycle are highly recrystallized; this alteration presumably reflects diagenetic effects that occurred during the hiatus or disconformity between the deposition of the two cycles rather than by later percolation of ground waters through relatively impermeable strata. The upper sample has 16 species, 14 percent planktonic specimens, and a tau value of 219. The assemblage is dominated by Cibicides, Spiroplectammina, Pyramidina, Bolivina, and Turrilina. This interval was deposited in the outer part of the inner neritic zone, probably at depths of 120-180 ft. The composition of the assemblage suggests lowered oxygen/high-productivity conditions. The lower sample suggests similar conditions, but probably was deposited at a slightly shallower water depth because the planktonic percentage decreases to five percent. The assemblage, dominated by Pulsiphonina, Nonion, Anomalinoides, and Bolivina, also suggests high-productivity/low-oxygen conditions.

The upper of the two Zone NP 11 cycles contains the deepest water deposits encountered in the Putneys Mill Paleogene strata. The middle and lower samples in this cycle contain 28 and 29 species, have 21 and 28 percent planktonic specimens, and have tau values of 588 and 812 . The dominant benthic genera include Gyroidinoides, Turrilina, Valvulineria, Epistominella, Cibicides, and Eponides, as well as a moderate number of Trifarina. This assemblage suggests deposition in inner middle to middle neritic depths of 180 to $300 \mathrm{ft}$, although it is probably closer to the deeper part of this range. The upper sample in this cycle indicates shoaling to inner neritic depths because the benthic species decrease to 23 , the planktonic specimens are only four percent, and the tau value is 87 .

The two samples in the Zone NP 12 sequence were deposited in the outer part of the inner neritic zone, or at depths of about $120-180 \mathrm{ft}$ or slightly deeper. The dominant genera are Valvulineria, Eponides, Anomalinoides, Bolivina, and Turrilina. The samples contain moderate species diversities of 22 and 24 species. The lower sample contains 14 percent planktonic specimens and has a tau value of 310 . A slight shoaling upward may be present as the upper sample has 8 percent planktonics and a tau value of 204.

The foraminiferal assemblages in the upper beds of the Nanjemoy, those placed in Zone NP 13, contain only a few highly recrystallized specimens. The difficulty in accurately identifying these few specimens, plus the presumed removal of most of the assemblage, does not allow any meaningful environmental interpretation of these beds. The diagenetic alteration of the assemblage presumably occurred during the erosional disconformity between the top of the Nanjemoy and the deposition of the overlying Piney Point beds. 


\section{Piney Point Formation}

The sand bed that is at the base of the lowest cycle of the Piney Point Formation (65-60 $\mathrm{ft})$, has 21 benthic foraminiferal species, a few planktonic specimens $(0.8$ percent), and a tau value of 17. The assemblage, which is dominated by Hanzawaia, Gyroidinoides, and Cibicides, has only a few specimens of the genera characteristic of low-oxygen/high-nutrient conditions that are found more abundantly in the overlying clay beds of this cycle. This sand bed was deposited in relatively well-oxygenated, inner neritic environments of from 60 - to 120 -ft depth or slightly less.

The interbedded sand and clay from 60 to $57 \mathrm{ft}$ also was deposited in shallow inner neritic depths of probably less than $120 \mathrm{ft}$. The assemblage is dominated by species of Hanzawaia and Valvulineria. It contains more specimens of the genera characteristic of highproductivity/low-oxygen conditions than are found in the underlying sand, but they are less abundant than in the overlying clay. The faunal composition suggests that these beds are transitional from the more oxygenated, inner neritic environments characteristic of the lower sand bed in the Piney Point to the lower oxygen environments found in the overlying clay.

The three samples from the clay beds of the lowest cycle (57-40 ft), contain moderate numbers of species (23-24), no planktonic specimens, and have tau values of less than 10. The tau values suggest that these clays were deposited in very shallow, inner neritic environments. The thin laminations of coarser sediment may indicate lower shore face, tidal flat environments, or a partially protected shallow-water environment. In addition to Hanzawaia and Cibicides, the assemblages contain abundant specimens of Pyramidina, Uvigerina, Guembelitria, Bolivina, and Epistominella. The abundance of these latter genera indicates that the clay-rich strata were deposited in a nutrient-rich/low-oxygen environment.

The sand of the overlying cycle disconformably overlies the clay beds and extends from 40 to $30 \mathrm{ft}$. The lowest assemblage in this sand represents deeper water deposition, but there is a considerable upward shallowing within this cycle. The basal sample in this cycle ( $39.5 \mathrm{ft})$, has a moderately high species diversity of 36 , and the assemblage is dominated by species of Asterigerina, Epistominella, Gyroidinoides, and Valvulineria. Planktonic specimens are fairly abundant, composing 14.9 percent of the assemblage, and the tau value is 536. The foraminiferal characteristics are considerably higher in this lower sample than those found in the samples farther up in this unit, and they suggest deposition in inner middle neritic depths of 150$240 \mathrm{ft}$. There is an upward decrease in diversity with 28 species at $33.5 \mathrm{ft}$ and 21 species at $31.1 \mathrm{ft}$, a decrease in the planktonic percentage with 1.5 and then 0.9 , and a resulting decrease in tau values with 42 and then 19 . The characteristics in the upper two samples suggest deposition in inner neritic depths of 60-120 ft.

One sample was examined from the 3-ft-thick, highly glauconitic sand cycle that represents the uppermost calcareous nannofossil zone of this formation (Zone NP 17). The sample has a moderate diversity of 29 benthic species, and Buccella, Cibicides, Elphidium, and Hanzawaia species are the most abundant. Planktonic specimens compose 2.6 percent of the assemblage, and they include both adult and juvenile Globigerina specimens. The tau value of the assemblage is 75 . The foraminifers suggest that this upper bed was deposited in the middle part of inner neritic depths of about 60-120 ft. Bottom conditions appear to have been well oxygenated. 
The above interpretations suggest that there are three depositional cycles in the Piney Point Formation in the Putneys Mill corehole. The lowest cycle was deposited entirely in inner neritic depths. There is some shallowing upward in this cycle into clayey environments that were somewhat depleted of oxygen. The clay beds represent either very shallow marine deposition, possibly in lower shore face or tidal flat environments on a mud-dominated shoreline, or they may represent somewhat protected environments. The second cycle is marked by having the deepest water, possibly inner middle neritic, environments at its base and then shallowing upward into inner neritic environments. The thin glauconitic sand at the top of the Piney Point presumably represents only a truncated lower part of the uppermost cycle. The remainder were removed erosionally before deposition of the overlying upper Oligocene beds of the Old Church Formation. These lower beds of the third cycle were deposited in inner neritic environments.

\section{Old Church Formation}

The one sample examined from this unit contains abundant foraminifers, but they are moderately to highly recrystallized. Some of the specimens may have been reworked from the underlying Piney Point Formation or other units as Poag (1989) found at Haynesville. The assemblage contains a moderate diversity of 24 benthic species, and species of Hanzawaia, Buccella, Cibicides, and Nonion are most abundant. Planktonic specimens compose 2.4 percent of the assemblage, and they include both adult and juvenile specimens of Globigerina. The tau value of the assemblage is 58. These characteristics suggest that at Putneys Mill, the Old Church Formation was deposited in inner neritic environments of less than 150-ft water depth, probably at depths of $60-120 \mathrm{ft}$, and the water was well oxygenated.

\section{CLAY MINERALOGY OF THE MARLBORO CLAY}

Gibson and others (1993) documented high kaolinite values for the uppermost Paleocene deposits in the Clayton corehole and drillhole 917 in New Jersey (fig. 1). The kaolinite proportion of the clay mineral suite increases from five percent or less in upper Paleocene deposits to peak values of 50-60 percent within the uppermost Paleocene. The kaolinite proportion begins to decrease in the very top of Zone NP 9 and rapidly decreases to low values of 5 percent or less in the lower part of Zone NP 10 (lowest Eocene).

Gibson and others (1994) showed that in Maryland and Virginia outcrop and subsurface sections this pattern of increasing kaolinite percentage in the uppermost Paleocene and decreasing percentage in the lowermost Eocene was repeated. The pattern can be used to correlate among localities and also to document the amount of erosional truncation that has occurred in sections of the Marlboro Clay.

The clay mineral suite was examined from four Marlboro Clay samples in the Putneys Mill corehole. Clay mineral analyses were performed with an X-ray diffractometer on samples taken from the $<2$-micrometer sediment fraction that were dried on glass slides. Percentages of clay minerals were estimated on the glycollated traces using the method of Soller (Soller and 
Owens, 1991), which is based upon techniques presented by Johns and others (1954), Biscaye (1965), and Brindley (1980).

Although the pattern of kaolinite increase and decrease in the latest Paleocene and earliest Eocene can be used to document the placement of strata in relation to the Paleocene/Eocene boundary in many partial sections of the Marlboro Clay, the relatively consistent, moderate kaolinite values found in the Marlboro strata in the Putneys Mill corehole do not clearly demonstrate whether we are in the lower to middle part of the kaolinite increase (latest Paleocene) or whether we are in the middle part of the kaolinite decrease (earliest Eocene). However, the sequence of red clay grading up into gray clay suggests placement in the earliest possible Eocene.

Table. 1. Percentage of kaolinite, illite, and illite/smectite in the Marlboro Clay in the Putneys Mill corehole.

\begin{tabular}{lcccc} 
& \multicolumn{3}{c}{ Depth } & \multicolumn{3}{c}{ Percentages } \\
\cline { 3 - 5 } Formation & (in feet) & Kaolinite & Illite & Illite/Smectite \\
Marlboro & $121.0 \mathrm{ft}$ & 16 & 64 & 20 \\
Marlboro & $122.6 \mathrm{ft}$ & 27 & 38 & 35 \\
Marlboro & $122.8 \mathrm{ft}$ & 21 & 28 & 51 \\
Marlboro & $125.0 \mathrm{ft}$ & 20 & 14 & 66
\end{tabular}

\title{
PUTNEYS MILL LITHIC SUMMARY
}

\begin{abstract}
Alluvium
$0-21 \mathrm{ft}$

sand and dark-gray clay with wood fragments and gravel near base.
\end{abstract}

\section{Old Church Formation}

$21-27 \mathrm{ft}$

clayey, fine to very fine sand; massively bedded with 10-20 percent glauconite; contains abundant mollusk shells; medium-green- to medium-dark-green.

\section{Piney Point Formation}

$27-30 \mathrm{ft}$

clayey, fine sand with bioturbated fabric composed of sand and olive-brown clay areas; highly glauconitic with 50-70 percent glauconite; scattered mollusk shells; dark-green. 
$30-38 \mathrm{ft}$

fine sand, massively bedded with less glauconite than above unit and with more calcareous matrix; scattered mollusk shells; medium-dark-green.

$38-40 \mathrm{ft}$

clayey, fine sand with $30-40$ percent glauconite; contains $1 / 2$-inch- to 1 -inch-thick clay laminae; dark-green.

$40-48 \mathrm{ft}$

clay, mostly massively bedded with bioturbation fabric composed of more clayey and more glauconitic sand areas in upper $2 \mathrm{ft}$ of unit, but with some glauconitic silt to very fine sand laminae 1-3 mm thick; contains shell fragments in middle and lower part of unit; light-medium-gray .

$48-57 \mathrm{ft}$

slightly silty clay, mostly massively bedded with some thin, 1- to 3-mm-thick silt laminae that contain a small amount of glauconite and fine shell fragments; light-medium-gray to light-grayish-pink.

$57-60 \mathrm{ft}$

interbedded, dark-green, clayey, fine sand and medium-gray sandy clay with interbeds as much as $0.5 \mathrm{ft}$ thick; sands contain 10 percent glauconite; abundant mollusk shells and shell fragments.

$60-65 \mathrm{ft}$

clayey, fine sand with bioturbation fabric composed of sand and dark-olive clay areas; abundant glauconite grains (up to 20 percent); contains medium to coarse quartz sand (sand grains commonly are stained green), fairly abundant mollusk shells; dark-olivegreen.

\section{Nanjemoy Formation}

\section{$65-78 \mathrm{ft}$}

clayey, very fine sand, containing mottled bioturbation fabric composed of sand areas and dark-olive, more clayey areas; abundant mica; glauconite grains compose 10 percent in upper part and as much as 30 percent in lower part; sand grains commonly are stained green; randomly scattered mollusk shells of small-sized clams and large Venericardia; scattered medium to coarse, well-rounded, quartz sand in lower part; dark-green.

78-84 ft

clayey, very fine sand, containing bioturbation fabric composed of sand areas and darkolive, silty clay areas; more clay than in above unit, abundant mica, scattered wellrounded, medium to coarse quartz sand and fine gravel that commonly is stained green; 
glauconite grains vary in abundance from 10 to 30 percent; fairly abundant, scattered, small to medium clam shells; dark-green.

$84-98 \mathrm{ft}$

fine sandy clay, containing bioturbation fabric composed of clay areas and more sandy areas; more clay than in above unit; both glauconite and phosphate grains occur; glauconite less abundant than in above unit, composing approximately 5 percent in the upper part and up to 15 percent in the lower part; has less mica than above unit, very sparse, scattered, small molluscan shell fragments in upper part, more abundant small to medium clams in lower part; shells usually scattered but also form a few shell layers about 1 inch thick; dark-olive to dark-greenish-black.

$98-102 \mathrm{ft}$

fine sandy clay, containing bioturbation fabric composed of clay areas and more sandy areas; glauconite and phosphate sand grains compose 10 percent; contains green-stained quartz grains, abundant scattered molluscan shells, pyrite nodules; medium-dark-grayishgreen.

$102-108 \mathrm{ft}$

no recovery.

$108-112 \mathrm{ft}$

silty to very fine sandy clay, containing bioturbation fabric composed of clay areas and more sandy areas; unit becomes more clayey toward the bottom; abundant mica, 5 percent glauconite, very sparse small shells, some carbonaceous debris in lower part; medium-dark-grayish-green.

$112-117 \mathrm{ft}$

no recovery.

$117-120.5 \mathrm{ft}$

silty clay, containing bioturbation fabric composed of clay areas with more silty to very fine sand areas, some mica; coarse sand-sized, soft glauconite grains scattered throughout unit; very few scattered small shell fragments; common pyrite nodules; base heavily burrowed into upper $1 \mathrm{ft}$ of underlying unit; medium-dark-greenish-gray.

\section{Marlboro Clay}

$120.5-122.7 \mathrm{ft}$

silty clay, massively bedded except for a few thin, 1-mm-thick dark laminae; gray. 


\section{$122.7-130 \mathrm{ft}$}

slightly silty clay, massively bedded with small amount of mica; contains $0.5-\mathrm{cm}$-sized localized pods of glauconitic fine sand; reddish-brown.

TD $130 \mathrm{ft}$

\section{ACKNOWLEDGMENTS}

We thank Elizabeth E. Hill for preparation of the foraminiferal samples and David R. Dowell for preparing the calcareous nannofossil samples. Jean M. Self-Trail prepared the illustrations. David B. Mason did the clay mineral analyses. We wish to thank David S. Powars and Robert E. Weems for their thoughtful reviews of this paper. 


\section{REFERENCES CITED}

Berggren, W.A., Kent, D.V., Flynn, J.J., and Van Couvering, J.A., 1985, Cenozoic geochronology: Geological Society of America Bulletin, v. 96, p. 1407-1418.

Biscaye, P.E., 1965, Mineralogy and sedimentation of Recent deep-sea clay in the Atlantic Ocean and adjacent seas and oceans: Geologic Society of America Bulletin, v. 76, p. 803-832.

Brindley, G.W., 1980, Quantitative X-ray mineral analysis of clays, in Crystal Structure of Clay Minerals and Their X-ray Identification, Brindley, G.W. and Brown, G. (eds.), Mineralogical Society Monographs, v. 5, p. 411-438.

Buzas, M.A., and Gibson, T.G., 1969, Species diversity: benthonic foraminifera in western North Atlantic: Science, v. 163, p. 72-75.

Bybell, L.M., and Gibson, T.G., 1991, Calcareous nannofossils and foraminifers from Paleocene and Eocene strata in Maryland and Virginia: IGCP Project 308 Field Trip Guidebook on Paleocene-Eocene boundary sedimentation in the Potomac River Valley, Virginia and Maryland, p. 15-29.

Bybell, L.M., and Self-Trail, J.M., 1995, Evolutionary, biostratigraphic, and taxonomic study of calcareous nannofossils from a continuous section in New Jersey: U.S. Geological Survey Professional Paper 1554.

Clark, W.B., and Martin, G.C., 1901, The Eocene deposits of Maryland: Maryland Geological Survey, Eocene volume, p. 1-92, 122-204.

Deck, L.T., 1984, Ostracodes of the Piney Point Formation, Pamunkey River, Virginia: in Ward, L.W., and Krafft, Kathleen, eds., Stratigraphy and paleontology of the outcropping Tertiary beds in the Pamunkey River region, central Virginia Coastal Plain Guidebook for Atlantic Coastal Plain Geological Association 1984 field trip, p. 186-191.

DiMarzio, J.A., 1984, Calcareous nannofossils from the Piney Point Formation, Pamunkey River, Virginia: in Ward, L.W., and Krafft, Kathleen, eds., Stratigraphy and paleontology of the outcropping Tertiary beds in the Pamunkey River region, central Virginia Coastal Plain - Guidebook for Atlantic Coastal Plain Geological Association 1984 field trip, Atlantic Coastal Plain Geological Association, p. 111-116.

Edwards, L.E., 1984, Dinocysts of the Tertiary Piney Point and Old Church Formations, Pamunkey River area, Virginia: in Ward, L.W., and Krafft, Kathleen, eds., Stratigraphy and paleontology of the outcropping Tertiary beds in the Pamunkey River region, central Virginia Coastal Plain - Guidebook for Atlantic Coastal Plain Geological Association 1984 field trip, p. 124-134.

Edwards, L.E., 1989, Dinoflagellate cysts from the Lower Tertiary formations, Haynesville cores, Richmond County, Virginia: U.S. Geological Survey Professional Paper 1489-C, p. C1-C12.

Frederiksen, N.O., 1984, Sporomorph correlation and paleoecology, Piney Point and Old Church Formations, Pamunkey River, Virginia: in Ward, L.W., and Krafft, Kathleen, eds., Stratigraphy and paleontology of the outcropping Tertiary beds in the Pamunkey River region, central Virginia Coastal Plain - Guidebook for Atlantic Coastal Plain Geological Association 1984 field trip, p. 135-149. 
Frederiksen, N.O., Gibson, T.G., and Bybell, L.M., 1982, Paleocene-Eocene boundary in the eastern Gulf Coast: Gulf Coast Association of Geological Societies Transactions, v. 32, p. 289-294.

Gibson, T.G., 1970, Late Mesozoic-Cenozoic tectonic aspects of the Atlantic Coastal Margin: Geological Society of America Bulletin, v. 81, p. 1813-1822.

Gibson, T.G., 1988, Assemblage characteristics of modern benthic Foraminifera and application to environmental interpretation of Cenozoic deposits of eastern North America: Revue de Paleobiologie, vol. special No. 2, p. 777-787.

Gibson, T.G., 1989, Planktonic benthonic foraminiferal ratios: Modern patterns and Tertiary applicability: Marine Micropaleontology, v. 15, p. 29-52.

Gibson, T.G., Andrews, G.W., Bybell, L.M., Frederiksen, N.O., Hansen, Thor, Hazel, J.E., McLean, D.M., Witmer, R.J., and Van Nieuwenhuise, D.S., 1980, Biostratigraphy of the Tertiary strata of the core: in Geology of the Oak Grove core, Virginia Division of Mineral Resources Publication 20, p. 14-30.

Gibson, T.G., and Buzas, M.A., 1973, Species diversity: patterns in modern and Miocene foraminifera of the eastern margin of North America: Geological Society of America Bulletin, v. 84, p. 217-238.

Gibson, T.G., and Bybell, L.M., 1991, Potomac River Paleocene and Eocene stop descriptions: IGCP Project 308 Field Trip Guidebook on Paleocene-Eocene boundary sedimentation in the Potomac River Valley, Virginia and Maryland, p. 85-124.

Gibson, T.G., and Bybell, L.M., 1994, Paleogene Stratigraphy of the Solomons Island, Maryland Corehole: U.S. Geological Survey Open-file Report 94-708, p. 1-35.

Gibson, T.G., and Bybell, L.M., in press, Sedimentary patterns across the Paleocene-Eocene boundary in the Atlantic and Gulf Coastal Plains of the United States: Geologie.

Gibson, T.G., Bybell, L.M., and Owens, J.P., 1992, Large-scale erosion of Cenozoic depositional sequences along the U.S. central Atlantic Coastal Plain [abs.]: Geological Society of America Abstracts, v. 24, no. 2, p. 16.

Gibson, T.G., Bybell, L.M., and Owens, J.P., 1993, Latest Paleocene lithologic and biotic events in neritic deposits of southwestern New Jersey: Paleoceanography, v. 8, p. 495514.

Gibson, T.G., Bybell, L.M., Owens, J.P., Mason, D.B., McCartan, Lucy, and Snow, J.N., 1994, Climatic and stratigraphic implications of clay mineral changes in Paleocene/Eocene boundary deposits of the northeastern U.S. [abs.]: Geological Society of America Abstracts, v. 26, no. 4, p. 15.

Glaser, J.D., 1971, Geology and mineral resources of southern Maryland: Maryland Geological Survey Report of Investigations 15, p. 1-84.

Grimsdale, T.R., and Van Morkhoven, F.P.C.M., 1955, The ratio between pelagic and benthonic Foraminifera as a means of estimating depth of deposition of sedimentary rocks: IV World Petroleum Congress, Proceedings, section I/D, Report 4, p. 473-491.

Johns, W.D., Brim, R.E., and Badley, W.F., 1954, Quantitative estimations of clay minerals by diffraction methods: Journal of Sedimentary Petrology, v. 24, p. 242-251.

Martini, Erlend, 1971, Standard Tertiary and Quaternary calcareous nannoplankton zonation: in Farinacci, Anna, ed., 2nd Planktonic Conference, Proceedings, Roma 1970, Edizioni Tecnoscienza, Rome, v. 2, p. 739-785. 
Mixon, R.B., Powars, D.S., Ward, L.W., and Andrews, G.W., 1989, Lithostratigraphy and molluscan and diatom biostratigraphy of the Haynesville cores - Outer Coastal Plain of Virginia: U.S. Geological Survey Professional Paper 1489-A, p. A1-A48.

Morrell, C.C., 1984, Cubitostrea from the Nanjemoy and Piney Point Formations: in Ward, L.W., and Krafft, Kathleen, eds., Stratigraphy and paleontology of the outcropping Tertiary beds in the Pamunkey River region, central Virginia Coastal Plain - Guidebook for Atlantic Coastal Plain Geological Association 1984 field trip, p. 183-185.

Nogan, D.S., 1964, Foraminifera, stratigraphy, and paleoecology of the Aquia Formation of Maryland and Virginia: Cushman Foundation for Foraminiferal Research, Special Publication 7, p. 1-50.

Olsson, R.K., and Wise, S.W., Jr., 1987, Upper Paleocene to middle Eocene depositional sequences and hiatuses in the New Jersey Atlantic margin: Cushman Foundation for Foraminiferal Research, Special Publication 24, p. 99-112.

Parker, F.L., 1954, Distribution of the foraminifera in the Northeastern Gulf of Mexico: Museum of Comparative Zoology (Harvard) Bulletin 111, No. 10, p. 453-588.

Perch-Nielsen, Katharina, 1985, Cenozoic calcareous nannofossils: in Plankton Stratigraphy, H.M. Bolli and others, eds., Cambridge University Press, New York, p. 427-554.

Poag, C.W., 1989, Foraminiferal stratigraphy and paleoenvironments of Cenozoic strata cored near Haynesville, Virginia: U.S. Geological Survey Professional Paper 1489-D, p. D1D20.

Reinhardt, Juergen, Newell, W.L., and Mixon, R.B., 1980, Tertiary lithostratigraphy of the core: in Geology of the Oak Grove core, Virginia Division of Mineral Resources Publication 20, p. 1-13.

Soller, D.R., and Owens, J.P., 1991, The use of mineralogic techniques as relative age indicators for weathering profiles on the Atlantic Coastal Plain, U.S.A., Geotherma, v. 51, p. 111-131.

Strickland, G.L., 1984, Molluscan biozones of the Piney Point Formation (middle Eocene, Claibornian Age) in the Pamunkey River valley, Virginia: in Ward, L.W., and Krafft, Kathleen, eds., Stratigraphy and paleontology of the outcropping Tertiary beds in the Pamunkey River region, central Virginia Coastal Plain - Guidebook for Atlantic Coastal Plain Geological Association 1984 field trip, p. 155-182.

Van Morkoven, F.P.C.M., Berggren, W.A., and Edwards, A.S., 1986, Cenozoic cosmopolitan deep-water benthic foraminifera: Bulletin des Centres de Recherches ExplorationProduction Elf-Aquitaine, Memoir 11, 421 p.

Ward, L.W., 1984, Stratigraphy of outcropping Tertiary beds along the Pamunkey River -Central Virginia Coastal Plain: in Ward, L.W., and Krafft, Kathleen, eds., Stratigraphy and paleontology of the outcropping Tertiary beds in the Pamunkey River region, central Virginia Coastal Plain -- Guidebook for Atlantic Coastal Plain Geological Association 1984 field trip, p. 11-78.

Ward, L.W., 1985, Stratigraphy and characteristic mollusks of the Pamunkey Group (lower Tertiary) and the Old Church Formation of the Chesapeake Group-Virginia Coastal Plain: U.S. Geological Survey Professional Paper 1346, p. 1-78.

Weems, R.E., 1984, Vertebrate biozones of the Pamunkey Group (Paleocene and Eocene, Maryland and Virginia): in Ward, L.W., and Krafft, Kathleen, eds., Stratigraphy and 
paleontology of the outcropping Tertiary beds in the Pamunkey River region, central Virginia Coastal Plain - Guidebook for Atlantic Coastal Plain Geological Association 1984 field trip, p. 198-204.

Weems, R.E., 1986, Geology of the Ashland quadrangle, Virginia: Virginia Division of Mineral Resources Publication 64 (scale 1:24,000).

Zullo, V.A., 1984, Barnacles from the Old Church Formation, Pamunkey River region, Virginia: in Ward, L.W., and Krafft, Kathleen, eds., Stratigraphy and paleontology of the outcropping Tertiary beds in the Pamunkey River region, central Virginia Coastal Plain -- Guidebook for Atlantic Coastal Plain Geological Association 1984 field trip, p. 192-197. 


\section{APPENDIX 1. On-Site Core Description}

0-18 ft: No coring, augered, alluvial sand.

Started coring at $18-\mathrm{ft}$ depth.

RUN 1, 18-22 ft:

4-ft core run, 4-ft recovery.

18-21 ft:

dark organic-rich clays, wood fragments, and gravel of alluvium.

-----MAJOR LITHOLOGIC CHANGE at $21 \mathrm{ft}$.

21-22 ft:

SAND, fine, slightly clayey, fairly well sorted; sand mostly subangular, massively bedded, abundantly glauconitic (10-15 percent); contains fairly abundant small to medium shells, abundant forams; medium-green.

22-23 ft: Augered, no recovery.

RUN 2, 23-27 ft:

4-ft core run, 4-ft recovery.

23-27 ft:

SAND, very fine, slightly clayey, fairly well sorted; sand is primarily subangular, massively bedded; glauconite varies from 10 to 20 percent; fair amount of poorly preserved small shell, abundant forams; bottom $0.5 \mathrm{ft}$ has slightly more shell and is more sandy and somewhat coarser with fine sand, 20 percent glauconite, darker green color than above; is nearing base of Old Church Formation; medium-dark-green.

$27-28 \mathrm{ft}$ : augered, no recovery.

-----LITHOLOGIC CHANGE

RUN 3, 28-32 ft:

4-ft core run, 4-ft recovery. 
28-30 ft:

SAND, fine with fair number of medium quartz grains, more clayey than $23-27 \mathrm{ft}$ interval, heavily glauconitic with 50-70 percent glauconite composed of both dark-green to black grains and light- to medium-green grains; contains some quartz grains that are green stained, olive-brown clayey patches of bioturbation fabric, sparse shell that is better preserved than in above unit; very dark green.

\section{----LITHOLOGIC CHANGE}

30-32 ft:

SAND, fine, more calcareous matrix and less glauconite than in above unit, scattered shell; lighter green color than above unit.

$32-33 \mathrm{ft}$ : Augered, no recovery.

\section{RUN 4, 33-35 ft:}

$2-\mathrm{ft}$ core run, $2-\mathrm{ft}$ recovery.

\section{3-35 ft:}

SAND, fine, massively bedded, calcareous.

35-36 ft: Augered through harder material, no recovery.

36-38 ft: Augered, no recovery.

RUN 5, 38- 42 ft:

4-ft core run, 4-ft recovery.

38-38.3 ft:

SAND, clayey, massively bedded, calcareous, glauconitic with some shell.

38.3-40 ft:

SAND, dominantly fine with fair number of medium sand grains, clayey; clayey laminae (from 1- to 2-cm thick) become more common, clay laminae have much less glauconite than sand which contains 30-40 percent glauconite; medium- to dark-green. 
40-42 ft:

CLAY, massively bedded with no lamination noted, contains burrows of glauconitic shelly sand from above unit; most burrow fills have high pyrite content; light-mediumgray.

42-43 ft: Augered, no recovery.

RUN 6, 43-47 ft:

4-ft core run, 4-ft recovery.

43-47 ft:

CLAY, generally massively bedded, but containing scattered $1-$ to 3 -mm-thick laminae at 5- to 8-cm intervals; laminae in upper $2 \mathrm{ft}$ are primarily slightly glauconitic silts to very fine sands; in bottom $2 \mathrm{ft}$ laminae become more glauconitic fine sand with shell fragments and abundant glauconite; light-medium-gray.

47-48 ft: Augered, no recovery.

RUN 7, 48-52 ft:

4-ft core run, 4-ft recovery.

48-52 ft:

CLAY, slightly silty; appears massively bedded but does have thin (about 1- to 3-mm thick) silt laminae that usually have a few shell fragments and some glauconite and pyrite; light-medium-gray to light-grayish-pink.

52-53 ft: Augered, no recovery.

RUN 8, 53-57 ft:

4-ft core run, 4-ft recovery.

53-56.7 ft:

CLAY, dominantly massively bedded but with a few thin (about $1 \mathrm{~mm}$ thick) silty laminae; scattered shell appears in clay about $2 \mathrm{ft}$ below the top and is continuous through rest of the clay interval; medium-gray. 
56.7-57 ft:

SAND, very fine, clayey; contains clay laminae, glauconite, abundant shells, mostly fragmented.

57-58 ft: Augered, no recovery.

RUN 9, 58-62 ft:

4-ft core run, 4-ft recovery.

58-60 ft:

SAND, olive-green and CLAY, olive-brownish-green; interbeds with several 0.5 -ft-thick intervals of mainly clay; sands are fine; bioturbation fabric is present; contains 10 percent glauconite with abundant shells and fragments.

60-61 ft:

SAND dominated interval with some $1-$ to 2 -cm-thick clay laminae.

61-62 ft:

SAND, fine with common medium to coarse sand grains that are well-rounded and polished, clayey with massive bedding; glauconite abundant (20\%), abundant random shells and shell fragments; medium-dark-olive-green.

62-63 ft: Augered, no recovery.

RUN 10, 63-67 ft:

4-ft core run, 4-ft recovery.

63-67 ft:

SAND, very fine with some medium to coarse grains that are well rounded and polished, clayey, massively bedded with abundant mica, bioturbation fabric of sand and dark-olive clay, fairly abundant shells; small to medium clams predominate; shells scattered in upper $2 \mathrm{ft}$, more concentrated in thin intervals in bottom $2 \mathrm{ft}$; many quartz grains and mica flakes have green staining; dark-green.

67-68 ft: Augered, no recovery.

RUN 11, 68-72 ft:

4-ft core run, 4-ft recovery. 
68-72 ft:

SAND, very fine with some coarse grains that are well rounded and polished, slightly clayey with less clay than in above interval, massively bedded, very micaceous with bioturbated fabric, 10 percent glauconite; sand grains are commonly green stained; abundant, scattered small clams and some large Venericardia; mottled dark-green, and dark-olive.

$72-73 \mathrm{ft}$ : Augered, no recovery.

RUN 12, 73-77 ft:

4-ft core run, 4-ft recovery.

73-77 ft:

SAND, very fine with scattered medium to coarse sand grains that are polished and well rounded, slightly clayey, massively bedded with bioturbated fabric, highly glauconitic (30 percent) with abundant mica; abundant scattered shell with common large Venericardia; dark-green sand areas mottled with dark-olive-brown clay areas.

77-78 ft: Augered, no recovery.

RUN 13, 78-82 ft:

4-ft core run, 4-ft recovery.

78-82 ft:

SAND, very fine with scattered medium to coarse sand and fine gravel that is well rounded and polished, moderately clayey, massively bedded with abundant mica; glauconite varies in abundance from 10 to 30 percent; contains bioturbated fabric of silty clay; moderately clayey, coarser grains are commonly green stained; fairly abundant scattered shell with small to medium clams most abundant; dark-green to dark-olive.

$82-83 \mathrm{ft}$ : Augered, no recovery.

RUN 14, 83-87 ft:

4-ft core run, 4-ft recovery.

83-87 ft:

CLAY, fine, sandy, massively bedded; contains bioturbated fabric with clay and sandy areas; mica less abundant than in above runs; small amount of glauconite, some rounded 
and polished; black grains appear to be phosphate; quartz grains still commonly green stained; very sparse, scattered fragments of small shells; mottled dark-olive- to darkgreenish-black.

87-88 ft: Augered, no recovery.

RUN 15, 88-92 ft:

4-ft core run, 4-ft recovery.

88-92 ft:

CLAY, very fine, sandy, massively bedded; bioturbation fabric of very fine sand and clay areas; contains fine, sand-sized, smooth black grains that appear to be phosphate; fairly abundant small to medium clams scattered throughout with some concentrated into 2-cm-thick intervals; shell more abundant than in above core run; mottled dark-greento dark-olive.

92-93 ft: Augered, no recovery.

RUN 16, 93-97 ft:

4-ft core run, 4-ft recovery.

93-97 ft:

CLAY, very fine, sandy, massively bedded; contains bioturbated fabric with pods of fairly clean, very fine sand in sandy clay; some black grains that could be phosphate and more abundant dark-green glauconite combined compose 5-15 percent; fairly abundant scattered shell; medium-dark-grayish-green.

97-98 ft: Augered, no recovery.

RUN 17, 98-102 ft:

4-ft core run, 4-ft recovery.

98-102 ft:

CLAY, fine sandy, massively bedded with bioturbation fabric of pods of cleaner sand in a dominantly clay matrix; glauconite and phosphate less abundant than higher in core (about 10\%); green-stained quartz grains, pyrite nodules, abundant scattered shell; medium-dark-grayish-green. 
102-108 ft: Augered, no recovery.

RUN 18, 108-112 ft:

4-ft core run, 4-ft recovery.

108-112.0 ft:

CLAY, silty to very fine sandy, massively bedded with small bioturbation pods of sandier material, abundant mica, small amounts of glauconite (about $5 \%$ ), very sparse shells, more in upper $2 \mathrm{ft}$ with only a few very small ones in lower $2 \mathrm{ft}$; lower $2 \mathrm{ft}$ is a more dense, massively bedded clay unit, but it still has sandy bioturbation pods, a little carbonaceous debris, abundant mica; medium-dark-grayish-green.

$112-117 \mathrm{ft}$ : changed to washing from augering, washed interval, no recovery.

RUN 19, 117-123 ft:

6-ft core run, 6-ft recovery.

$117-120.5 \mathrm{ft}:$

CLAY, silty, fine, sandy, massively bedded with bioturbation fabric of silty to fine sandy pods in more clayey areas; coarse, soft, sand-sized blobs of glauconite scattered throughout (about 5\%), some mica, pyrite nodules common, a few very small shell fragments; medium-dark-greenish-gray.

-----MAJOR LITHOLOGIC CHANGE, heavily burrowed contact with burrows of overlying silty clay extending for $1 \mathrm{ft}$ into underlying clay unit.

120.5-122.7 ft:

CLAY, massively bedded with some thin, 1-mm-thick silty laminae, more blocky clay than above with less silt and no mica; gray.

122.7-123 ft:

CLAY, very slightly silty, massively bedded; brick red.

123-124 ft: Washed interval, no recovery.

RUN 20, 124-130 ft:

6-ft core run, 6-ft recovery. 


\section{$124-130 \mathrm{ft}:$}

CLAY, slightly silty, massively bedded, micaceous; has small pods of glauconitic fine sand that commonly are $0.5 \mathrm{~cm}$ in size; these pods may be bioturbation fabric but they look more like self-contained concentrations; at $129.7 \mathrm{ft}$ is a small clam with thin shell preserved; brick-red.

Total depth - $130 \mathrm{ft}$

\section{APPENDIX 2. Calcareous Nannofossil Species Listed in Paper}

Blackites creber (Deflandre in Deflandre \& Fert, 1954) Stradner \& Edwards

Blackites scabrosus (Deflandre in Deflandre \& Fert, 1954) Roth, 1970

Blackites spinosus (Deflandre \& Fert, 1954) Hay \& Towe, 1962

Blackites tenuis (Bramlette \& Sullivan, 1961) Sherwood, 1974

Braarudosphaera bigelowii (Gran \& Braarud, 1935) Deflandre, 1947

Braarudosphaera undata Stradner, 1959

Campylosphaera dela (Bramlette \& Sullivan, 1961) Hay \& Mohler, 1967

Cepekiella lumina (Sullivan, 1965) Bybell, 1975

Chiasmolithus bidens (Bramlette \& Sullivan, 1961) Hay \& Mohler, 1967

Chiasmolithus consuetus s.1. (Bramlette \& Sullivan, 1961) Hay \& Mohler, 1967

Chiasmolithus eograndis Perch-Nielsen, 1971

Chiasmolithus grandis (Bramlette \& Riedel, 1954) Hay, Mohler, \& Wade, 1966

Chiasmolithus solitus (Bramlette \& Sullivan, 1961) Hay, Mohler, \& Wade, 1966

Chiasmolithus titus Gartner, 1970

Chiphragmalithus calathus Bramlette \& Sullivan, 1961

Coccolithus eopelagicus (Bramlette \& Riedel, 1954) Bramlette \& Sullivan, 1961

Coccolithus pelagicus (Wallich, 1877) Schiller, 1930

Cribrocentrum reticulatum (Gartner \& Smith, 1967) Perch-Nielsen, 1971

Cruciplacolithus tenuis (Stradner, 1961) Hay \& Mohler in Hay et al., 1967

Cyclagelosphaera prima (Bukry, 1969) Bybell \& Self-Trail, 199-

Cyclococcolithus formosus Kamptner, 1963

Cyclococcolithus neogammation Bramlette \& Wilcoxon, 1967

Daktylethra punctulata Gartner in Gartner \& Bukry, 1969

Dictyococcites bisectus (Hay, Mohler, Wade, 1966) Bukry \& Percival, 1971

Dictyococcites daviesi (Haq, 1968) Perch-Nielsen, 1971

Dictyococcites scrippsae Bukry \& Percival, 1971

Discoaster barbadiensis Tan Sin Hok, 1927

Discoaster binodosus Martini, 1958

Discoaster deflandrei Bramlette \& Riedel, 1954

Discoaster diastypus Bramlette \& Sullivan, 1961

Discoaster distinctus Martini, 1958

Discoaster elegans Bramlette \& Sullivan, 1961

Discoaster kuepperi Stradner, 1959 
Discoaster limbatus Bramlette \& Sullivan, 1961

Discoaster lodoensis Bramlette \& Riedel, 1954

Discoaster mediosus Bramlette \& Sullivan, 1961

Discoaster minimus Sullivan, 1964

Discoaster multiradiatus Bramlette \& Riedel, 1954

Discoaster saipanensis Bramlette \& Riedel, 1954

Discoaster salisburgensis Stradner, 1961

Discoaster sublodoensis Bramlette \& Sullivan, 1961

Ellipsolithus bollii Perch-Nielsen, 1977a

Ellipsolithus distichus (Bramlette \& Sullivan, 1961) Sullivan, 1964

Ellipsolithus macellus (Bramlette \& Sullivan, 1961) Sullivan, 1964

Ericsonia obruta Perch-Nielsen, 1971

Ericsonia subpertusa Hay \& Mohler, 1967

Fasciculithus tympaniformis Hay \& Mohler in Hay et al., 1967

Goniolithus fluckigeri Deflandre, 1957

Helicosphaera bramlettei (Müller, 1970) Jafar \& Martini, 1975

Helicosphaera compacta Bramlette \& Wilcoxon, 1967

Helicosphaera lophota (Bramlette \& Sullivan, 1961) Locker, 1972

Helicosphaera seminulum Bramlette \& Sullivan, 1961

Lithostromation operosum (Deflandre in Deflandre \& Fert, 1954) Bybell, 1975

Lithostromation perdurum Deflandre, 1942

Lithostromation simplex (Klumpp, 1953) Bybell, 1975

Lophodolithus nascens Bramlette \& Sullivan, 1961

Markalius inversus (Deflandre in Deflandre \& Fert, 1954) Bramlette \& Martini, 1964

Micrantholithus aequalis Sullivan, 1964

Micrantholithus flos Deflandre in Deflandre \& Fert, 1954

Micrantholithus vesper Deflandre, 1954

Nannotetrina fulgens (Stradner, 1960) Achuthan \& Stradner, 1969

Neochiastozygus concinnus (Martini, 1961) Perch-Nielsen, 1971

Neococcolithes dubius (Deflandre in Deflandre \& Fert, 1954) Black, 1967

Pemma balium Bybell \& Gartner, 1972

Pemma basquense (Martini, 1959) Bybell \& Gartner, 1972

Pemma basquense crassum (Bouche, 1962) Bybell \& Gartner, 1972

Pontosphaera bicaveata (Perch-Nielsen, 1967) Romein, 1979

Pontosphaera exilis (Bramlette \& Sullivan, 1961) Romein, 1979

Pontosphaera fimbriata (Bramlette \& Sullivan, 1961) Romein, 1979

Pontosphaera multipora (Kamptner ex Deflandre, 1959) Roth, 1970

Pontosphaera pectinata (Bramlette \& Sullivan, 1961) Sherwood, 1974

Pontosphaera plana (Bramlette \& Sullivan, 1961) Haq, 1971

Pontosphaera punctosa (Bramlette \& Sullivan, 1961) Perch-Nielsen, 1984

Pontosphaera rimosa (Bramlette \& Sullivan, 1961) Roth \& Thierstein, 1972

Pontosphaera vadosa Hay, Mohler, \& Wade, 1966

Pontosphaera versa (Bramlette \& Sullivan, 1961) Sherwood, 1974

Pontosphaera vesca (Sullivan, 1965) Aubry, 1986 
Pontosphaera wechesensis (Bukry \& Percival, 1971) Aubry, 1986

Reticulofenestra floridana (Roth \& Hay in Hay et al, 1967) Theodoridis, 1984

Reticulofenestra hillae Bukry \& Percival, 1971

Reticulofenestra pseudolockeri Jurasova, 1974

Reticulofenestra umbilica (Levin, 1965) Martini \& Ritzkowski, 1968

Rhabdosphaera gladius Locker, 1967

Rhabdosphaera morionum (Deflandre \& Fert, 1954) Bramlette \& Sullivan, 1961

Rhomboaster bramlettei (Brönnimann \& Stradner, 1960) Bybell \& Self-Trail, 1995

Rhomboaster contortus (Stradner, 1958) Bybell \& Self-Trail, 1995

Rhomboaster orthostylus (Shamrai, 1963) Bybell \& Self-Trail, 1995

Sphenolithus anarrhopus Bukry \& Bramlette, 1969

Sphenolithus moriformis (Brönnimann \& Stradner, 1960) Bramlette \& Wilcoxon, 1967

Sphenolithus orphanknolli Perch-Nielsen, 1971

Sphenolithus radians Deflandre in Grasse, 1952

Syracosphaera clathrata Roth \& Hay in Hay et al, 1967

Toweius occultatus (Locker, 1967) Perch-Nielsen, 1971

Toweius pertusus (Sullivan, 1965) Romein, 1979b

Transversopontis exilis (Bramlette \& Sullivan, 1961) Perch-Nielsen, 1971

Transversopontis pulcher (Deflandre in Deflandre \& Fert, 1954) Perch-Nielsen, 1967

Transversopontis pulcheroides (Sullivan, 1964) Baldi-Beke, 1971

Transversopontis zigzag Roth \& Hay in Hay et al., 1967

Zygodiscus herlyni Sullivan, 1964

Zygrhablithus bijugatus (Deflandre in Deflandre \& Fert, 1954) Deflandre, 1959 